\title{
Plansız Gebelik Sürecindeki Kadınların Dini, Manevi ve Psikolojik Durumlarının İncelenmesi*
}

\section{Investigation of Religious, Spiritual and Psychological Conditions of Women During Unintended Pregnancy Period **}

\author{
Amine Hümeyra BULDUR, Sorumlu Yazar, Doktora Öğrencisi. \\ İstanbul Üniversitesi Sosyal Bilimler Enstitüsü, İstanbul / Türkiye \\ aminehumeyra@gmail.com \\ https://orcid.org/0000-0001-6187-077X
}

Gülüşan GÖCEN, Doç. Dr.

İstanbul Üniversitesi İlahiyat Fakültesi, İstanbul / Türkiye

gulusan.gocen@istanbul.edu.tr

https://orcid.org/0000-0003-4856-9653

ISSN: 1303-880X

e-ISSN: 2667-7504

http://ded.dem.org.tr

Makale Türü / Article Type:

Araştırma Makalesi / Research Article

Geliş Tarihi / Received Date: 13.10.2021

Kabul Tarihi / Accepted Date: 26.11.2021

Yayın Tarihi / Published Date: 25.12.2021

Tr/En: $\mathrm{Tr}$

Intihal / Plagiarism: Bu makale, en az iki hakem tarafindan incelendi ve intihal içermediği teyit edildi. / This article has been reviewed by at least two referees and scanned via a plagiarism software.
Atıf/Citation: Buldur, A.H. \& Göcen, G. (2021). Plansız gebelik sürecindeki kadınların dini, manevi ve psikolojik durumlarının incelenmesi. Değerler Eğitimi Dergisi,19 (42), s. 337-374

https://doi.org/10.34234/ded.1009333

* Bu çalışma, İstanbul Üniversitesi Sosyal Bilimler Enstitüsü'ne bağlı olarak Haziran 2020 tarihinde tamamlanmış "Plansız Gebeliklerde Manevi Desteğin Rolü” isimli Yüksek Lisans Tezi'nin bir bölümünden üretilmiştir.

**This study was produced from a part of the Master's Thesis titled "The Role of Spiritual Support in Unintended Pregnancies", which was completed in June 2020, affiliated to the Istanbul University Institute of Social Sciences. 
Öz: Bu makalenin amacı; plansız gebelik yaşayan anne adaylarının, gebeliği ve anneliği anlamlandırma biçimlerini incelemek, anneliğe geçiş sürecindeki bu kritik dönemde deneyimledikleri tecrübeleri dini, manevi ve psikolojik yönleriyle ele alarak din psikolojisi perspektifiyle bir resim çizmeye çalışmaktır. Durum deseninde hazırlanan bu nitel saha araştırmasında, amaçlı örnekleme tiplerinden kartopu ve ölçüt örnekleme ile seçilmiş 21-38 yaş aralığında (ort. 28,7), mevcut durumda plansız gebelik yaşayan, 11'inin ilk gebeliği, 6'sının ikinci gebeliği, 7'sinin üçüncü gebeliği, 1'inin ise dördüncü gebeliği olan, ağırlıklı olarak lisans ve lisansüstü eğitime sahip, 12'sinin aktif olarak çalışmakta olduğu 25 evli Müslüman kadın ile yarı yapılandırılmış görüşmeler yapılmıştır. Betimsel ve içerik analizi ile yapılan çözümlemeler sonucunda; plansız gebelik yaşayan kadınların yaşadıkları duygusal yoğunlukla mücadele etmek için dini ve manevi başa çıkma yöntemlerini kullandıkları (i), hem aile ve sosyal çevrelerinden hem de bu alandaki profesyonellerden manevi destek almaya ihtiyaçlarının olduğu (ii) tespit edilmiştir. Ayrıca katılımcıların gebeliklerini ilk öğrendikleri andaki duygu hallerinde "şaşkınlık ve şok" alt teması baskın gelirken (iii), anneliği anlamlandırma biçimlerinde nitelendirdikleri en yoğun kavram "sorumluluk" alt teması olmuştur (iv). Bir anne adayını bebeğini dünyaya getirip getirmeme noktasında nelerin arada bırakabileceğine dair sebepler listesinde ise "ekonomik durum" ve "eşi ile ilişkisi" alt temaları ön plana çıkmıştır (v).

Anahtar Kelimeler: Gebelik, Plansız Gebelik, Din Psikolojisi, Dini Başa Çıkma.

\section{$\&$}

Abstract: The aim of this study is to examine the ways in which expectant mothers who have had an unintended pregnancy make sense of pregnancy and motherhood, and to try to draw a picture from the perspective of the psychology of religion by considering the religious, spiritual and psychological aspects of their experiences during this critical period in the transition to motherhood. In this qualitative field study, phenomenological approach was employed with conducting semi-structured interviews with 25 married Muslim women, 12 of whom are actively working, majority of them have completed undergraduate and graduate education and whose ages varies from 21 to 38 (mean 28.7), selected by snowball and criterion sampling tapproaches of purposeful sampling methods, 11 of them had their first pregnancy, 6 of them had their second pregnancy, 7 of them had their third pregnancy and 1 had their fourth pregnancy. The results obtained from descriptive and content analysis have indicated that women who experienced unintended pregnancy use religious and spiritual cop- 
ing methods to combat the emotional intensity they experience (i), and they need moral support from both their family and social circles and professionals in this field (ii). In addition, while the sub-theme of "surprise and shock" was dominant in the emotional states of the participants when they first learnt about their pregnancy (iii), the concept they described most intensely in the way they made sense of motherhood was the sub-theme of "responsibility" (iv). The subthemes of "economic status" and "relationship with her spouse" came to the fore in the list of reasons that affect the descision of mother-to-be about giving birth to her baby (v).

Keywords: Psychology, Pregnancy, Unintended Pregnancy, Psychology of Religion, Religious Coping.

(The Extended Abstract is at the end of the article.)

\section{Giriş}

Ebeveyn olma kararını vermek her zaman planlı ve bilinçli bir şekilde olmamaktadır. Kadınların gebeliğe ve doğuma karşı tutumları, gebeliğin planlı olup olmasına göre farklılık gösterebilmektedir. Gebelerin, gebeliklerine dair algıları kendilerini, fetüsü ve doğuma dair davranışlarını etkileyen önemli unsurlardandır. Planlı gebelik; istenen ve güvenli bir şekilde sürdürülen gebelik olarak nitelendirilirken, plansız gebelik; ilerleyen süreçte istendiği durumda güvenli, istenmediği durumda ise kürtaja götüren gebelik olarak tasvir edilmektedir (Abajobir vd., 2017; Ersoy vd., 2015; Karaçam vd., 2010; Arslan ve Mete, 2005).

Plansız gebelik; bireysel, ailevi ve sosyal etkileri ile dünya genelinde yaygın bir problem olarak görülmektedir. Küresel olarak baktığımızda gebeliklerin \%40'1 plansızdır (Abajobir vd., 2017) ve her yıl yaklaşık 80 milyon kadın plansız gebelik yaşamaktadır (Ersoy vd., 2015). Hem gelişmiş hem de gelişmekte olan ülkelerde yaygın olan plansız gebelikler; uzun vadede anne ve bebek için çeşitli olumsuz sonuçlar doğurduğu için, özellikle gelişmekte olan ülkelerde sıklığı azaltılmaya çalışılan başlıca problemlerdendir (Ersoy, 2015). Bu gebeliklerin olumsuz sonuçları öncelikle anneyi, bebeği ve aileyi, dolaylı olarak da toplumu etkilemektedir (Bahk vd. 2015; Arslan ve Mete, 2004). Bu sebeple, plansız gebeliğin olumsuz sonuçlarını azaltmaya yönelik çalışmaların yapılabilmesi için, öncelikli olarak plansız gebeliğin doğası ve gebe üzerindeki etkileri üzerine araştırmaların yapılması önem arz etmektedir.

Türkiye'de her sene 1.183.652 doğum gerçekleşmektedir (TÜIK, 2019). Bunların ise \%26'sı plansızdır. Türkiye Nüfus ve Sağlık Araştırması sonuçlarına 
göre (2018); plansız gebelik oranlarının yüksek olmasının sebebi, 15-49 yaş arası kadınların \%63'ünün daha fazla doğum yapmak istememesine karşılık yalnızca \%49'unun modern kontraseptif (korunma) yöntemleri kullanmasından kaynaklanmaktadır.

Ülkemizde ve yurtdışında plansız gebeliklerin doğum sonrası etkileri üzerine pek çok araştırma yapılmıştır. Örneğin Taner (2014) araştırmasında plansız gebeliklerin doğum sonrası etkilerini incelemiş ve erken dönemdeki annelik davranışları üzerinde olumsuz etkisinin olduğu sonucuna ulaşmıştır. Khajehei (2015) de araştırmasında; plansız gebelik yaşayan anne adaylarının gebelik s1rasında veya doğumdan sonra ruhsal bozukluk yaşama olasılıklarının çok daha yüksek olduğunu söylemektedir. Karamustafa (2017) ve Bahk (2015) da plansız gebelik yaşayan kadınların doğum sonrası depresyon (pospartum depresyon) yaşama riskinin daha yüksek olduğu sonucuna ulaşmıştır. Plansız gebelik ile ruh sağlığı arasındaki ilişkiyi inceleyen Ali (2016) plansız gebelik yaşayan kadınların ruh sağlıklarının bozulma olasılığının 9,19 kat daha fazla görüldüğünü ifade etmiştir.

İnsanlık tarihi kadar eski olan aile planlaması uygulamalarıyla kişiler, istedikleri zaman, istedikleri sayıda çocuk sahibi olmak için birtakım doğum kontrol yöntemlerine yönelmiş ve hala da yönelmektedir. Hayatındaki büyük yaşam olaylarından birisi üzerinde doğum kontrol yöntemleriyle yüzde yüz kontrol gücü olmadığını bilmesine rağmen bir bebek sürpriziyle karşılaştı̆̆ında hayal kırıklığına uğramaktadır. Plansız gebeliğin sebep olduğu psikolojik ve fizyolojik problemler, özellikle kadının yaşam kalitesine etki etmekte ve bu durumla baş etmekte güçlük çekmektedir. Bu ruhsal bunalım halinden sıyrılmaya çalışırken, anne adayı yalnızca fiziksel ve psikolojik değil aynı zamanda sosyal ve manevi yönden de değişiklik yaşamaktadır.

Gebelikte dini yaşam ve maneviyatın etkisine dair yapılan çalışmalara baktığımızda; Pargament vd. (2007) kadınların plansız gebelik sürecinde maneviyatı iyileştirici bir anahtar olarak gördüklerini belirtirken, Yali ve Lobel (1999) gebelik sürecinde kadınların \% 86'sının manevi başa çıkma mekanizması kullandığını söylemiş, Pakzad vd. (2018) manevi yaşam tarzının gebeliğe ilişkin stres düzeyini ne düzeyde etkilediğine dair yaptıkları çalışmada, katılımcıların hayatları manevi yaşam tarzıyla daha uyumlu olduğunda, gebeliğe özgü daha az stres yaşadıkları sonucuna ulaşmıştır. Gebelik döneminde manevi yaşamı inceleyen Mutmainnah ve Afiyanti de (2019), gebelik süreci, doğum ve doğum 
sonrasında manevi anlamlandırma biçiminin gebenin güven, motivasyon, sebat ve psikolojik dayanıklılığını artırdığını tespit etmiştir.

İnsanın biyopsikososyal ve manevî açıdan iyi olma halinin bütüncüllüğü gebeler için de geçerlidir ve insan olmak, tam iyilik hali içine olmayı gerektirmektedir. Maneviyatı insan doğasının en temel boyutu olarak gören Jung'un (2005) da işaret ettiği gibi tüm insani meselelerin maneviyatla bağlantıları olduğunu ve bunları görmeden tam bir iyileşmenin mümkün olmayacağının kabul edilmesi gerekmektedir. Bu sebeple gebelik gibi insanın yaşam dönemeci olan bir sürecin sadece fiziksel biyolojik ve psikolojik özellikleri üzerinde yoğunlaşıp manevi yönünün göz ardı edilmesi de insana bütüncül yaklaşmanın önünde büyük bir engel teşkil etmektedir (Gügen, 2019). Zira manevi boyut, kişiye derin bir anlam ve amaç sağlamaktadır (Uysal, 2021). Bu anlam ve amaç kazanımı ise kişiye sıkıntı ve zorluk yaşadığı durumlarda umut kaynağı olabilmekte ve sorunlarıyla başı çıkmasında farklı bir perspektif sunabilmektedir. Bu nedenle, tam manasıyla bir iyileşmeden bahsetmek için fiziksel, duygusal ve bilişsel işleyişin yanı sıra manevi işleyişin de dikkate alınması gerekmektedir (Hill ve Pargament, 2015).

\section{Yöntem}

\section{Araştırmanın Modeli}

$\mathrm{Bu}$ çalışmada, gebeliği plansız olan anne adaylarının, bu süreç içerisindeki tecrübelerini dini, manevi ve psikolojik yönüyle derinlikli bir şekilde incelemek amacıyla nitel araştırma yöntemi tercih edilmiştir. Araştırma deseni olarak durum çalışması kullanılmıştır. Durum çalışmalarında; araştırılan kişi, kurum, grup veya ortam ile bir olgu ya da yaşam olayının insanlar tarafindan etkileşimine dair kapsamlı bilgi edinme imkanı bulunabilmektedir (Yıldırım ve Şimşek, 2016; Büyüköztürk vd., 2014). Durum çalışmasına uygun olarak da yarı yapılandırılmış görüşme tekniği tercih edilmiştir. Nitel araştırmalarda görüşme tekniği; zengin betimlemelere olanak sağlamakta, verilerin çeşitliliği, derinliği, dokusu ve duygusu ile daha çok ilgilenmektedir (Neuman, 2017).

\section{Araştırmanın Çalışma Grubu}

Amaçlı örnekleme yöntemlerinden kartopu örnekleme yönteminden yararlan1lan bu çalışmada; ölçüt örnekleme kullanılarak, halen gebelik döneminde olan, 
plansız bir şekilde gebe kalmış olsa da doğum yapmaya karar vermiş gebeler çalışmaya alınmıştır. Gebeliklerinin trimester dönemleri (üç aylık period) noktasında bir sınırlamamaya gidilmemiş, her dönemden gebe çalışmaya dâhil edilmiştir. Müslüman ve evli olan, 21-38 yaş aralığında 25 plansız gebenin 16's1 İstanbul'da, 5'i Konya'da, 2'si Ankara'da, 2'si Yalova'da yaşamaktadır. Katı' lımcıların 1'i ilköğretim mezunu, 8'i lise mezunu, 13'ü üniversite mezunu, 3'ü ise yüksek lisans mezunudur. Katılımcılardan 1'i fizyoterapist, 1'i işletmeci, 1'i, mimar, 1'i fotoğrafçı, 1'i avukat, 4'ü, muhasebeci, 3'ü psikolog, 7'si öğretmen ve 6's1 ev hanımı olduğunu belirtmiştir. Katılımcıların 12'si aktif olarak çalışmakta, 13'ü ise çalışmamaktadır. 11'i, sosyo ekonomik durumlarını "iyi”, 12'si “orta”, 1'i “ortanın altı" ve 1'i “zayıf” olarak nitelendirmiştir. Evlilik uyumunu 7 'si “çok iyi”, 10'u "iyi”, 5'i “orta”, 3'ü ise "zayıf” olarak değerlendirmiştir. 9'u, çocuk bakımında kendilerine yardım eden birilerinin olduğunu söylerken, 16'sı bu konuda destek aldığı birisini belirtmemiştir. Katılımcıların 20'si normal doğum yapmayı planlarken 5'i sezeryan doğum gerçekleştirecektir. Katılımcılardan 6'sı gebelik sürecinde tıbbi bir problem yaşarken 19'u yaşamamıştır. Katılımcıların 11'i ilk gebeliğini yaşarken 6'sı ikinci gebeliğini, 7'si üçüncü gebeliğini, 1’i ise dördüncü gebeliğini yaşamaktadır.

\section{Veri Toplama Aracının Oluşturulması}

TÜBİTAK projesi kapsamında "Kadınlarda Görülen Depresyonla Mücadelede Dini/Manevi Başa Çıkma Stillerinin Rolü” konusunda gebe polikliniklerinde araştırmacı olarak görev alırken, gebelerden gelen geri bildirimler, plansız gebelik özelinde müstakil bir çalışma yapılmasına ihtiyaç olduğunu düşündürmüştür. Aynı dönemde psikolog olarak çalışmakta olduğum anne-çocuk merkezinde de plansız gebelik yaşayan kadınların azımsanmayacak kadar çok olduğuna şahitlik etmek ve çevremde bu tecrübeyi yaşayanları fark etmek bu konuya olan ilgimi artırıp ciddiye alarak çalışmaya sevk etmiş ve bu iki çalışma sahası bu çalışmanın katılımcılarına ulaşma noktasında ilk bağlantı noktaları olmuştur.

Yurtiçi ve yurtdışı kaynaklarda yapılan çalışmaları incelendiğinde özellikle yurt içinde plansız gebelik yaşayan kadınların manevi yaşamlarına dair bir çalışma yapılmadığı görülmüştür. İlgili literatür taranarak, ulaşılan çalışmalardan bir soru havuzu elde edilmiş, sonrasında buradan benzer soruların elenmesi ve araştırma sorularına hizmet eden maddelerin öne çıkartılmasıyla bir taslak oluşturulmuştur. Görüşme formunun hazırlanmasında soruların kolay anlaşılabilecek, odaklı, açık uçlu, yönlendirmeden kaçınan, çok boyutlu olmayan, farklı tür- 
leri barındıran ve mantıklı bir biçimde sıralanmasına dikkat edilmiştir (Yıldırım ve Şimşek, 2006). Taslak form, görüşme sorularının geçerliliğini, içerik ve yapı bakımından değerlendirilmesini sağlamak amacıyla nitel araştırma tekniklerini çalışmalarında sıklıkla kullanan, Din Psikolojisi ve Eğitim Bilimleri alanlarında uzman iki akademisyene ve iki klinik psikoloğa gönderilmiş ve onlardan gelen görüş ve öneriler doğrultusunda yeniden düzenlenmiştir. Ana uygulamaya geçilmeden önce 4 kişi ile ön görüşme yapılmış ve soruların uygulanabilirliği test edilmiş, soruların anlaşılıp cevaplanabilir olup olmadıkları değerlendirilmiştir. Nihayetinde görüşme sorularına kişisel bilgi formu eklenerek İstanbul Üniversitesi Sosyal ve Beşeri Etik Kurulu'na (6606), sunulmuş ve gerekli onay alınmış veri toplama aracı uygulanabilir hale getirilmiştir.

\section{Verilerin Toplanması ve Analizi}

Araştırmanın verileri 2018 yılının Ağustos-Kasım ayları arasında yazarın psikolog olarak görev yaptı̆̆ anne-çocuk merkezine gelen kadınlardan ve onların çalışmadan haberdar ederek katılımlarını teşvik ettikleri çevrelerinden toplanmıştır. Görüşmeler; İstanbul'da ikamet eden katılımcılar ile yüzyüze, İstanbul dışında yaşayan katılımcılar ile online (görüntülü) ortamda gerçekleştirilmiştir. Katılımcıların hepsine çalışmanın bilimsel bir araştırma olduğu, kişisel hiçbir verilerinin paylaşılmayacağı konusunda bilgilendirme yapılmış ve verdikleri yanıtların çalışmada kullanılması konusunda hem alıntılama hem de ses kaydı izni alınmıştır. Ortalama 50-60 dakika süren görüşmeler, katılımcıların izniyle araştırmacı tarafından ses kaydına alınarak muhafaza edilmiştir. Katılımcıların isimleri gizli tutulmuş, her birine isim yerine katılımcı numaraları verilmiştir.

Görüşme sırasında alınan ses kayıtları dijital ortamdan yazıya aktarılarak çözümlemesi yapılmış; veriler, betimsel ve içerik analiziyle değerlendirilmeye çalışılmıştır. Araştırmanın geçerlik ve güvenirliği için elde edilen bulgular araştırma yöntemleri konusunda uzman akademisyenlere iletilmiş, gelen tavsiye ve önerilerin ışığında temalar oluşturulmuştur. Araştırmanın bulguları, plansız gebelerin, gebeliklerini öğrenme süreçlerinde deneyimlediklerine dair altı alt tema altında; (i) "şaşkınlık, şok”, (ii) "üzüntü”, (iii) “endişe kaygı, korku”, (iv) "ağlama hissi”, (v) "sevinç ve mutsuzluk birlikte, duygu karmaşası", (vi) "engellenmişlik", plansız gebelerin ideal gebelik tasavvuruna ilişkin dört alt tema olarak; (i) istekli ve planlı olmak", (ii) "fizyolojik ve psikolojik olarak hazır olmak", (iii) "çocuklarının arasında yeterli yaş farkının olması" ve (iv)"eş desteği almak", anneliğin anlamlandırılmasına dair sekiz alt tema altında; (i) "süper 
kahraman olmak", (ii) "sorumluluk sahibi olmak", (iii) "merhametli olmak", (iv) "sabırlı olmak", (v) "fedakar olmak", (vi) "karşılıksız, koşulsuz, sonsuz sevgi”, (vii) "mucize, lütuf, nimet”, (viii) "arkadaş olmak", plansız gebelik yaşayan kadınların, bebeklerini dünyaya getirip getirmeme konusunda arada bırakan sebepler yedi alt tema altında; (i) "ekonomik durum", (ii) "eşi ile ilişkisis", (iii) "sorumluluk almaya hazır hissetmemeleri", (iv) "sağlık problemleri”, (v) "halihazırda çocuk sahibi olmak", (vi) "ailevi sorunlar", (vii) "korku, kaygı" plansız gebeliklerde dini-manevi başa çıkmaya ilişkin üç alt tema altında; (i) "dua etmek", (ii) "namaz kılmak", (iii) "kur'an okumak" ve plansiz gebelerin manevi destek uzmanlarından beklentilerine dair iki üst tema altında; (i) "rehberlik etmesi beklentisi”, (ii) "motive etmesi beklentisi”" şekillenmiş ve bulgular araştırmacının gözlemleri ile desteklenerek yorumlanmıştır.

\section{Bulgu ve Yorum}

\section{Plansız Gebeliğin Psikolojisi ve Anlamlandırma Süreci}

Hayat, sıradanlığı bozan sürprizlerle doludur. Kişiler, alışageldikleri düzen, yer ve kişiler içerisinde herhangi bir kesinti veya değişiklik yapmadan yaşarken kendilerini daha güvende hissetmektedir. Plansız gebelik ise kişiler için beklenmedik olaylardan birisidir. Bu çalışmanın araştırma sorusu olan "gebeliğin psikolojisi ve fizyolojisi göz önünde bulundurulduğunda, plansız olmasının anneliğe geçişte nasıl bir etkisi olmaktadır?" sorusuna cevap bulmak amacıyla katılımcilara bu beklenmedik gebeliklerini öğrendiklerinde ne hissettikleri sorulduğunda yaşadıkları duyguları "şaşkınlık, şok" (K1, K3, K7, K8 K9, K15, K16, K17, K18, K21, K22, K23), üzüntü (K2, K5, K6, K8, K10, K11, K12, K14, K16, K21, K24), "endişe, kayg1, korku” (K2, K4, K5, K7, K8, K9, K12, K13, K15, K19, K20, K22, K23, K25), "ağlama hissi” (K4, K5, K6, K11, K13, K21, K22, K23, K24), "sevinç ve mutsuzlukla birlikte, bir duygu karmaşası" (K2, K7, K8, K9, K13, K14, K17,K20, K22, K25) ve “engellenmişlik” (K4, K8, $\mathrm{K} 9, \mathrm{~K} 16)$ alt temalatı ile ifade etmişlerdir.

"Şaşkınlık, şok” duygusu, plansız gebeliğgin ilk öğrenildiğinde yaşanılan hisler içinde listesinin en başında gelmiştir. Menstrüel siklustaki (adet döngüsü) değişiklikten şüphelenerek, ihtimal vermeseler de gebelik testi yapmaya karar veren katılımcilardan birisi: "Eşimle test yaparak öğrendik ama eşim çok emindi gebe olmadiğımdan boşuna yapıyoruz diyordu. Tabi ikimizde büyük şok yaşa- 
dık hatta eşim ilk gebeliğimdeki test ile şaka yaptığımı düşündü, şoku atlatmak uzun sürdü” (K7) sözleriyle, test sonucu karşısındaki şaşkınlığını dile getirmiştir. Sürprizler, duygusal tecrübelerimizin yoğunluğunu etkileyen, biliş ve duygu arasındaki önemli bir bağlantıdır (Mellers vd., 2013). Bu çalışmada da katılımcıların; plansız gebeliklerini öğrendikleri an karşılaştıkları sürprize karşı ilk tepkileri duygusal yoğunluk olmuştur. K6'nın “Ilk başta büyük şok yaşadım, ne yapacağımı bilemedim. Öleceğimi zannettim, zaten ilk başta hep yok saydım" sözleriyle ifade ettiği gibi, ilk etapta hemen hemen tüm katılımcılar adeta kilitlenmiş ve fonksiyonlarını kısa süreliğine de olsa yitirdiklerini vurgulamışlardır.

Plansız gebeliğin öğrenilmesi sürecinde en sık yaşanılan duygulardan ikincisi “üzüntü” alt teması olmuştur. Üzüntü, hayal kırıklığı ve umutsuzluğu içinde barındıran çok temel ve doğal bir duygudur. Genelde bir kayıp hissi ile tetiklenir ve ulaşılamayan bir amaca yanıt verme biçimidir. Üzüntünün temel işlevi yaşantıları gelecekte daha iyi duruma getirmek için motivasyonu artırmaktır. Aynı zamanda üzüntü duygusu, kişinin kendisini korumak amacıyla geliştirdiği bir savunma mekanizmasıdır (Joaquim vd., 2018). Katılımcıların gebeliklerini öğrendiklerinde üzüntü duyduklarını ifade etmeleri, bu minvalde okunduğunda daha iyi anlaş1lacaktır. "Öğrendiğimde ne kadar üzüldü̆̆̈̈mü anlatamam. 5 haftalık hamileydim ve evliliğimin ikinci aylydı daha çok erken olduğunu, kendimi asla hazır hissetmediğimi bu bebeğe bakamayacağımı düşünüyordum" (K5). Gebeliğini öğrendiği andaki hislerini hayal kırıklığı ve umutsuzluk içerisinde yaşadığı üzüntü olarak açıklayan katılımcı, beklediği desteği elde ettikten sonra daha iyi hale geldiğini söylemiştir.

"Endişe, kaygl ve korku" alt temaları da plansız gebeliğin öğrenilme sürecinde yaşanılan duygular listesinde kayda değer bir yer almıştır. Hayatın planlandığı gibi gitmemesi, çoğu zaman can sıkıcı olabilmektedir. Plansız gebelik yaşayan katılımcıların da tecrübe ettiği bu yaşam olayı hayatlarının her yönüne nüfuz ettiği için onları derinden etkilemektedir. K8'in de ifade ettiği üzere: "Bazı işle alakalı planlarımın aksayacağını düşünerek engellenmiş gibi hissettim, yarım kalacaktı her şey" plansız gebelik kadınların yıllarca emek vererek ulaştığ işiyle ilgili hayatında bir gerileme olarak görüldüğünde endişe ve korku duygularına yol açmaktadır.

Plansız gebelik sürecinde olan kadınların iş yerlerindeki ortamlarından aldıkları geri dönütler de bu duruma olumsuz etki edebilmektedir: "İş yerinde ne tepki alacağımı düşündü̈m ve işten çıkarılacağımı bildiğim için çok üzüldüm. İsimi seviyorum ve tecrübe kazanmak istiyorum ama bu hayalimi biraz rafa 
kaldırmam gerekecek" diyen K16, çalışma ortamında gebeliğinin bir kriz olarak algılanmasından dolayı üzüntü duymaktadır. Destekleyici bir ortam ve esnek çalışma düzenlemeleri, plansız gebenin bir nebze olsun teselli olmasını sağlayabilmekteyken, işini kaybetme korkusuyla yüz yüze gelen gebe için durum pek iç açıcı olmamaktadır. Duygusal stresine ek olarak hem maddi hem de statü kaybı yaşayacak olan gebenin stresi K16'da olduğu gibi giderek katlanabilir.

Plansız gebelik yaşayan anne adaylarının, planlı gebelik yaşayanlara kıyasla daha endişeli oldukları görülmektedir (Schetter ve Tanner: 2012). Destek eksikliği hissetmeleri durumunda endişeleri daha da artmaktadır (Deklava vd., 2015). Bu bulgular, katılımcıların verdiği cevaplar göz önüne alındığında şaşırtıcı değildir. Anne adayları çok hazırlıksız yakalandıkları bu duruma kaygılı yaklaşmışlar, çevrelerinden gelecek tepkilerden çekinmiş ve ne hissettiklerine odaklanma noktasında sıkıntı yaşamışlardır. Bir katılımcı, gebeliğini ilk öğrendiği zamanları "İçimde tereddütler vardı ama gerçekle yüzleşince duygularım birbirine girmişti ve kabullenememiştim, bir sürü soru vardı kafamda hepsinden kaçmak istiyordum" (K15) diyerek her şeyden uzaklaşıp olan biteni yok saymak ve gerçeklerden kaçmak istediğini söyleyerek ifade etmiştir. Hissettikleri kaygının dozunu artıran büyük faktörün yakın çevrelerinin nasıl karşılayacağına dair soru işaretlerinin olduğunu belirten katılımcılardan birisi de bu durumu; "Değişik bir duyguydu hem şimdi olmamallydı diye düşündüm hem sevinç duydum hem üzüntü hissettim. Bir yandan da kemirip duran bir kaygl vardl. Eşimin ve ailemin nasıl tepki vereceğini çok merak ettim" (K2) sözleriyle açıklamıştır.

\section{Plansız Gebelerin İdeal Gebelik Tasavvuru}

Katılımcılara zihinlerindeki ideal gebelik özelliklerini öğrenmek amacıyla "tekrar gebe kalacak olsalar neyi değiştirmek isteyecekleri” sorulduğunda çoğunluğu, gebelik süreciyle ilgili aynı kalmasını istedikleri şeylerden ziyade değiştirmeyi dilediklerine odaklanmıştır. Değiştirmeyi istedikleri şeylerin ise; "istekli ve planlı olmak" (K1, K2, K6, K7, K11, K18, K19, K22, K23), "fizyolojik ve psikolojik olarak hazır olmak" (K4, K14, K17, K18, K21), “çocuklarının arasında yeterli yaş farkının olması" (K1, K3, K7, K21) ve "eş desteği almak" (K7, K10, K16, K21, K25) gibi alt temalar altında toplandığı tespit edilmiştir:

Tekrar gebe kalacak olurlarsa; ancak çocuk sahibi olmayı düşündükleri, arzu ettikleri ve geleceğe dönük düşünceleri arasında yer vermeye başladıkları bir zamanda olmayı isteyeceklerini söyleyen katılımcılardan birisi "Keşke maddi ve manevi olarak hazır olsaydım daha ciddiye alsaydım ve gerçekten karar ver- 
dikten sonra hazır bir şekilde bebek yapmaya karar verseydik, bir daha planlı bir çocuk dünyaya getirmeyi isterdim" (K19) demiştir. Bulundukları şartların henüz gebe kalmak için uygun olmadığını düşünen katılımcılar, ideal gebelik tasvirlerini de bunun üzerinden yapmışlar, şartların gebeliklerini planlayacak ölçüde yerine gelmesini ve böylece istekli davranacakları bir gebelik arzuladıklarını ifade etmişlerdir.

Katılımcıların nazarındaki ideal gebelik tasvirinde bir diğer etmen; bir dahaki gebeliğin hem fizyolojik hem de ruh sağlıklarının kendilerini tatmin ettiği ve bir çocuk sahip olmaya elverişli bir durumda olduklarına kanaat ettikleri zamanda gerçekleşmesi yönünde olmuştur. "Hamile kalmadan önce sağllğımla ilgili daha detaylı bir taramadan geçip hamile kalmak isterim. Değiştirme şansım olsaydı hamile kalmadan önce bir talasemi taşıyıcısı olduğumu bilmek isterdim" diyen (K4), fizyolojik durumu hakkında gebelik öncesinde daha fazla bilgiye sahip olmayı istediğini söylerken, K18; "Hamilelikten uzun süre önce sigarayı bırakmış olmayı isterim. Bu bana zaman zaman suçlu hissettiriyor" sözleriyle, sağlığına daha dikkat ettiği ve daha bilinçli olduğu bir dönemde gebe olmayı isteyeceğini söylemiştir. Ruh sağlıklarının daha stabil olduğu, duygusal ve davranışsal işlevlerini rahat bir şekilde sürdürebildikleri bir dönemde gebe kalmay1 isteyeceklerini belirten katılımcılardan birisi şu sözleri söylemiştir; "Ruhsal halimin, eşimle aramın daha iyi olmasını, daha iyi şartlar altında ögrrenmeyi isterdim" (K14). Gelişim ögelerinden birisi olarak kabul edilen ve daha çok öğrenme sürecinin gerekliliği olarak kullanılan "hazır bulunuşluk" kavramının, katılımcıların verdikleri cevaplardan referansla, gebelikte de önemli olduğu, gebelerin yaşayacakları sürece dair önceden bilgi sahibi olmalarının, yeterlilik hisleri ve motivasyonlarını önemli ölçüde etkileyeceği düşünülmüştür.

Bir daha gebe kalacak olsa, değiştirmek isteyeceği şartların çocuklarının arasındaki yaş farkı olacağını söyleyen K1, bu isteğini şöyle ifade etmiştir: "Diğer çocuklarımın büyümesini isterdim. Emen bir çocuğum var sonuçta. Bu kadar stres yapmazdım eğer 2-3 sene sonra olsaydl". Katılımc1ların cevaplarına bakt1ğımızda; çocuklarının arasındaki yaş farkının az olmasının, iş yüklerini ve streslerini artırdığını vurguladıkları, yaş farkının daha fazla olması durumunda daha müreffeh bir gebelik geçireceklerini düşündükleri görülmektedir.

Yeniden gebe kalmaları durumunda, şu anki gebeliklerinden farklı olarak, eşlerinin kendilerine daha çok destek olmasını ve gebelik sürecinde daha aktif rol oynamasını isteyen katılımcılardan birisi şu ifadeleri kullanmıştır: "Eşimin daha hazır ve istekli olmasını ve daha çok destek vermesini isterdim" (K16). 
Gebelik süreçlerinde eşlerini yeterli ölçüde yanlarında hissetmeyen katılımc1lar, kendi istekleri veya yönlendirme ile onların da süreçlerine dahil olmasını arzu ettiklerini ifade etmişlerdir.

\section{Anneliğin Anlamlandırılması}

Annelik, toplumun her kesiminde kutsal olduğu düşünülen ve oldukça önem atfedilen rollerden birisidir. Anneliğin kadınlığın ayrılmaz bir parçası ve içgüdüsel bir duygu olduğu, kadına verilen en değerli ve imtiyazlı bir görev olduğu söylemleri yeniden inşa edilerek farklı formlarda karşımıza çıkmaktadır (Tuğrul, 2018).

Katılımcılara, bu çalışmanın araştırma sorusu olan "gebeliğin psikolojisi ve fizyolojisi göz önünde bulundurulduğunda, plansız olmasının anneliği anlamlandırmada nasil bir etkisi olmaktadır?" sorusuna cevap bulmak amaciyla, onlara anne olmanın anlamı sorulduğunda "süper kahraman olmak" (K5, K7), "sorumluluk sahibi olmak" (K1, K3, K5, K7, K9, K13, K15, K18, K19, K20, K21, K22), "merhametli olmak" (K2, K14, K20, K22), "sabırlı olmak" (K2, K22, K6), "fedakâr olmak" (K13, K15, K22), "karş1lıksız, koşulsuz, sonsuz sevgi” (K2, K6, K12, K17, K18, K19) , "mucize, lütuf, nimet” (K4, K8, K10, K11, K14, K15, K16), "arkadaş olmak" (K12, K19, K20) gibi cevaplar gelmiş, tüm katılımcıların karş1lıksızlık, sevgi ve fedakârlık temelinde birleştiği görülmüştür.

Katılımcıların anneliği en yoğun olarak nitelendirdikleri kavram "sorumluluk" alt teması olmuştur. Bu sorumlulukları yerine getirmenin oldukça zor olduğuna dikkat çekmek için katılımcılardan, normal insanların yapamadığı şeyleri yapma güçlerine sahip olan ve bu güçlerini toplumun iyiliği için kullanan karakter olan "süper kahraman" benzetmesini yapanların olduğu görülmüştür. "Keşfetmek, ögrrenmek, olabildiğinin en iyisi olmak için sürekli çalı̧̧mak, sorumluluklarını yerine getirmeye çalışmak, her işe yetişmek ve asla yorulmamak. Annelik, tam anlamıyla bence süper kahramanlık demek" (K5). "Emanet edilmiş bir can, annelik sorumluluğunu kaldırabilmek için kesinlikle ayrı bir güç geliyor bence anneye, bazı durumlarda süper kahraman gibi bile hissedebiliyorsun" (K7). Katılımcıların, sorumluluklarına insanüstü bir anlam yükleyerek yaşadıkları durumların daha da özel hale geldiğini betimledikleri görülmektedir.

Her toplumda çocuk yetiştirme uygulamaları ve çocuk bakımı, toplumun kültürel normlarına uygun olarak gerçekleşmektedir. Anneler kendilerini sorumlu ebeveynler olarak görmekte ve bu nedenle bebeklerinin sağlığı ve refahı için 
tehdit oluşturabilecek risklerden kaçınmak için çok daha fazla çaba göstermektedir. Bakıma muhtaç bir varlığa gösterdiği ihtimamı, katılımcılardan birisi "Sizden bir parça oluyor, size ait. Onun canı acısa sizin de acıyor. Etrafinızda sizden bir parça var, size muhtaç. Çok büyük bir sorumluluk bence annelik, bir an bile aklından çıkmıyor" (K1) diyerek sorumluluğunu ihtiyaçlarını gidermekle mükellef olması bakımından açıklarken, K3; "Bana göre anne olmanın anlamı sadece çocuk doğurmak değil, ondan sorumlu olmak, çocuğunu her anlamda iyi yetiştirmek, ruh sağllğını korumak ve çocuğun manevi ihtiyaçlarını karşılayabilmektir" diyerek bu mesuliyetin dünyaya getirmekle bitmediği bilakis yeni başladığını; fiziksel, duygusal ve manevi ihtiyaçlarını da göz önünde bulundurmak gerektiğini ifade etmiştir.

Günümüz modern dünyasında artık bir ebeveynin tıp, pediatri, çocuk psikolojisi, beslenme bilimi gibi alanlarda asgari ölçüde bilgiye sahip olması beklenmektedir. Anneler kendilerini adeta bir sınava hazırlanıyormuş gibi hissetmekte ve sorumlu oldukları konulara itinayla hazırlanmaya çalışmaktadır. Bu sorumluluk hissinin kendilerini yetiştirme ve geliştirme konusunda bir motivasyon aracı olsa da zaman zaman yıkıcı ve yıpratıcı duygulara da zemin hazırladığı görülmektedir: Bir katılımc1 "Yeni bir dünya kurmak, büyük bir sorumluluğun üstesinden gelmek. Doğru yaptığından emin olmaya çalışmak, hep bir sınavdaymışsın gibi. Çok yorulduğumu ve yetişemeyeceğimi hissediyorum bazen" (K9) diyerek kendisinin sürekli sınandığını düşündüğünü ve yaşadıklarının üstesinden gelmekte zorlandığını ifade ederken, bir başka katılımcı ise; "Çok büyük bir sorumluluk, fedakarlık. Artık kendi hayatımın planını değil doğmamış kızımın hayatının planın yapıyorum. Anne olmak gelecek demek. Her anlamda kendimi yetiştirmeye çalışıyorum" (K13) demiş ve bu sorumluluğunun altından kalkmaya çalışmak için çözümü kendisini sürekli güncellemeye çalışmakta bulduğunu ifade etmiştir.

Katılımcıların annelik sorumluluğu üzerinde yoğun olarak durdukları ve mesuliyetlerinin annelik rolü üzerinde vazgeçilmez bir yeri olduğunu vurguladıkları görülmektedir. Murphy (2000); kadınların kendilerini "bebeklerinin sağlı̆̆ını ve refahını geliştirmek ve sürdürmekle görevli olan, aktif sorumlu ve rasyonel anneler" olarak inşa ettiklerini ileri sürmektedir. Hatta bunu bir boyut ileriye taşıyıp anneliğin artık ahlaki bir girişim olarak lanse edildiğini, çocuklarının sağlığını ve refahını korumayı ihmal etmenin "anneleri ahlaken hesap verebilir hale getirdiği” algısının benimsenmeye başladığını söylemektedir (Liamputtong, 2009). Çocukların sağlığını ve refahını sağlayamayan anneler, 
sorumlu hareket edemeyen kişiler olarak görülme riski taşıyacaktır. Sonuç olarak, annelerin "ahlaklı, sorumlu ve ihtiyatlı kişi”" kimlikleri, toplum tarafindan verilen sorumluluk bilincinin ağırlığıyla tehdit edilecektir.

Katılımcıların annelik üzerinde durduğu bir diğer alt tema "karşılıksız, koşulsuz, sonsuz sevgi” olmuştur. Fromm'a (1985) göre anne sevgisinin koşulsuz olmasının sebebi, çok özel bir yapısının olmasının sonucudur. Karşısındakini önceleyen ve bencil olmayan yapısından dolayı anne sevgisi, sevgilerin en yüce türü ve tüm duygusal bağların en kutsalı olarak kabul edilmektedir. Manap ve diğerlerine (2015) göre anne sevgisi çocuğuna fiziksel, duygusal ve manevi bir dokunuştur. Bu dokunuşun gücü çocukların benlik saygısını, motivasyonunu, başarısını ve mutluluğunu beslemektedir.

Katılımcılardan odaklandığı bir başka alt temanın "merhamet" olduğu görülmüştür. Anne çocuk ilişkisinin seyrinde doğumla birlikte oluşan bağın zaman geçtikçe merhamete ve sevgiye dönüştüğü görülmektedir (Yıldız, 2019). Katılımcıların birçoğu anneliği aynı zamanda "mucize, lütuf, nimet" alt teması ile nitelendirmiştir. Örneğin; "Kadın olmanın manasıdır bence annelik. Çok güzel bir şey, büyük bir nimet" diyerek anneliğe çok büyük bir mânâ yükleyen K4, kadınlığın ancak anne olmakla bir anlam kazandığını ifade etmiştir. Duygularını daha derin bir şekilde ifade eden bir katılımcı da anneliğin kendisinde uyandırdı̆̆g etkiyi "Tuhaf bir şey, bazen çok güçlü, bazen de çaresiz hissettiren bir şey. Bir kadını kökten değiştiren, dönüş̧üren, sıcacık duyguları açı̆̆a çıkarıveren sarsıcl, muhteşem bir deneyim, mucize gibi" (K14) sözleriyle ifade etmiş ve bir dizi duygular silsilesi yaşadığını belirtmiştir.

\section{Plansız Gebelik Yaşayan Kadınların Bebeklerini Dünyaya Getirip Getirmeme Kararını Verme Süreci}

Gebe olduğunu öğrendiği andan itibaren her kadının bebeğini dünyaya getirip getirmeyeceğine dair karar vermesi gereken bir süreç başlamıştır. Dini hassasiyetleri olan her anne adayı, kendi sağlığ için bir risk unsuru olmadığ1 müddetçe bebeğinin yaşama hakkına müdahale edemeyeceğine inanmaktadır. Nitekim kürtaj neredeyse tüm dinler tarafından yasaklanmıştır (Hedayat vd., 2006). Plansız gebeliklerde, anne adayı her ne kadar mensubu olduğu dinin izin vermediğini veya sadece etik olmadığını bilse de onu arada bırakacak bazı sebeplerden dolayı kürtajı düşünmekte, yeltenmese bile en azından aklından geçirebilmektedir. 
Katılımcılara bu çalışmanın araştırma sorusu olan "plansız gebelik yaşayan kişileri bebeği dünyaya getirme kararını verirken arada bırakan ve motive eden sebepler nelerdir?" sorusuna cevap bulmak amacıyla bir anne adayını bebeğini dünyaya getirip getirmeme noktasında nelerin arada bırakabileceği sorulmuş ve hemen hemen hepsi en az bir sebep söylemişlerdir. Anne adaylarına bu soruyu kendileri üzerinden sormanın psikolojik bir bariyer etkisi yaratacağ 1 ve etki altında kalmalarına sebep olacağı için soru formatı üçüncü tekil kişinin dilemmasına yönelmiş gibi düzenlenmiştir. Nitekim bu soruya verilen cevapların katılımcıların kendi hikâyeleriyle örtüştüğü görülmüştür. Bir anne adayını bebeğini dünyaya getirme noktasında nelerin arada bırakabileceğine dair sebepler listesini "ekonomik durum" (K1, K6, K8, K11, K12, K16, K18, K21), "eşi ile ilişkisi” (K8, K10, K11, K13,K14, K17, K20, K22), "sorumluluk almaya hazır hissetmemeleri” (K4, K8, K15, K16, K17, K19, K20, K22, K26), "sağl1k problemleri” (K2, K5, K13), "hâlihazırda çocuk sahibi olmak" (K3, K20, K23), "ailevi sorunlar" (K1, K2, K8, K11), "korku, kayg1" (K13, K15, K22, K23) gibi alt temalar oluşturmuştur.

Bir bebek haberi öğrenildiği andan itibaren ailenin gider bütçesine bir kalem daha eklenmektedir. K6, bir bebeğin masraflarının doğum öncesinde başladığını şu sözleriyle dile getirmiştir: "Daha doğmadan başlyyor masraflar, özel hastaneler ateş pahası, doğumu alelade bir hastanede yapmak istemez kimse. Sonrasında bebeğe bakım şartları var, maddi durumun iyi olsa bunları üstesinden gelmek çok kolay, sanırım bir anneyi en çok maddi yetersizlik arada birakabilir" (K6). Annenin yükünü hafiffletmenin yolunun maddi koşullara bağlı olduğunu ifade eden K6, bu şartlar sağlanmadığında hepsine kendisinin yetmesi gerektiğini düşünen anne adayının bu yükün altında ezileceğini vurgulamaktadır.

Temelde "her çocuk rızkıyla gelir" teslimiyetine sahip gelenekten geldikleri anlaşılan katılımcıların, bir taraftan da hayatlarındaki alım gücü standartlarının yükselmesiyle sorunları aşma potansiyelinin de doğrudan artacağını varsayan bir yaklaşım izledikleri görülmektedirÖrneğin bir katılımc1; "Bence ekonomik sebepler arada birakabilir ancak. Diğer tüm sebepler ortadan kalkar bu iyi olduğunda çünkü mesela çocukların arasındaki yaş farkının azlı̆̆ı bile problem olmaktan çıkar, her türlü destek alabilirsiniz durumunuz iyi olduğunda. Psikoloğa da götürebilirsiniz, istediğiniz eğitimi de aldırırsınız vs." (K21) sözleriyle ideal çocuk büyütme senaryosunda, ekonomik gelirin iyi olmasının olmazsa olmaz unsurlardan birisi olduğuna dikkat çekmiştir. Ona göre, ortaya çıkacak olan problemlerin çözümü noktasında imdada ilk koşacak olan faktör finansal kaynaklar olacaktır. 
Bebeği dünyaya getirme noktasında gebenin en çok etkilendiği faktörlerden ikincisi "eşi ile ilişkisi” alt teması olmuştur. İlişkiler, gelişimsel değişimleri ve geçişleri kolaylaştırmak ve olumsuz yaşam olaylarının etkisinde tampon görevi görmek için oldukça önemlidir. Özellikle ebeveynliğe geçiş sırasında olduğu gibi stres, kırılganlık ve gelişimsel zorluk seviyeleri yüksek olduğunda, ilişkiler bireyin psikolojik uyumuna katkıda bulunabilmektedir (Figueiredo vd., 2008). Bununla birlikte, ilişkiler stresli olayların müsebbibi olabilir ve sonuç olarak bireyin psikolojik sağlığını olumsuz yönde etkileyebilir. Ebeveynliğe geçiş esnasında eşin sağladığı ilişki ve desteğin oldukça önemli olduğunu vurgulayan katılımcılardan birisi; "Eşimden başka hiçbir sebep çocuğumu doğurmama engel olamaz. Ĕğer eşim istemediğini söyleseydi sanırım tek başıma cesaret edemezdim ya da çok zorlanırdım" (K10) sözleriyle eşinin desteğinin bebeğini dünyaya getirmeye karar vermesinde büyük ölçüde rol oynadığını belirtmiştir. Gebelikte kadınlar eşlerine ve onlardan gelen desteğe daha bağımlı hale gelmektedir (Rosand vd., 2011). Eş desteği; bir kadının gebeliğini isteme veya istememe kararında etkin olan ana bileşenlerden birisi olarak görülmektedir. Kroelinger ve Kathryn (2000), gebelerle yaptıkları bir çalışmada bir eşin gebelik sırasındaki desteğinin ve endişesinin, annenin hamileliği gerçekleştirme arzusu için olumlu sonuçlar doğurduğunu tespit etmişlerdir. İlişkinin dirayeti, eşin güvenilirliği, desteği ve gebeliğe karşı hisleri, anne adayının gebeliğine dair kararlarını ve deneyimlerini etkilemektedir.

Gebeliğini devam ettirip ettirmemeye karar verme noktasında gebelerin en çok etkilendiği alt temalardan üçüncüsünün, "kendilerini sorumluluk almaya hazır hissetmedikleri” olduğu görülmüştür. İlk iki faktöre göre bağlamı çok daha geniş olsa da temelde kastedilenin bir çocuğun tüm ihtiyaçlarını karşılamaya, onu çok sevmeye, kendisine daha az zaman ayırmaya, daha fazla strese, maddi ve manevi olarak her şeyiyle onun için seferber olmaya hazır olmadıkları anlamlarında kullanıldığı görülmüştür. Örneğin bir katılımc1, "Bir canın sorumluluğunu alabiliyor olmak gerek. Bundan sonraki tüm hayatını ona göre şekillendirmeye cesaret edebilmek aynı zamanda. Bunlara hazır olduğunu düşünmezse arada kalır illa ki" (K4) sözleriyle anneliğin yepyeni bir hayata başlangıç olduğunu ve bu hayata geçme cesaretini kendisinde bulamamayı hazırlıksız olmak olarak nitelendirmiştir.

Gebeliklerini öğrenme sürecinde katılımcılar yaşadıkları duygular içinde kayg1 ve korkunun da arada kalmaya sebep olabileceğini söylenmiştir. Örneğin bir katılımcı, "Kaygı arada bırakabilir en çok. Her gebenin kaygı düzeyi ve hayat 
şartları farklı olduğu için kimisi maalesef kürtajla sonuçlanıyor, kimisi tüm bu sorunlarla başa çıkıp yoluna bebeği ile devam ediyor" (K23) diyerek, kaygısını kontrol altına alıp mücadele etmeyi başarabilenlerin bebeğini dünyaya getirme noktasında kararlı olabileceklerini fakat kaygılarına yenik düşüp başa çıkamayanların ise kararsız kalabileceklerini ifade etmiştir.

Gebelerin kaygılarını artıran ve arada kalmalarına sebep olan bir diğer alt tema da halihazırda çocuklarının olmasıdır. Henüz daha emzirdiği bir bebeğinin olması veya çocuğunun daha öz bakımını yapacak yeterliğe gelmemiş olması onları daha fazla telaşlandırmaktadır. Bir katılımc1, "Benim iki kızım var mesela ve daha çok küçükler. Onlara haksızlık edecekmişim gibi geldi çocuk doğurarak bu beni çok arada bıraktı" (K3) sözleriyle, küçük çocuğunun olmasının gebenin duygusal yükünü nasıl artırdı̆̆ını çok net bir şekilde özetlemektedir. Sadece kendi mesaisinin artacağına değil, aynı zamanda bu durumdan etkilenecek olan çocuklarının ruh haline de odaklanarak meşakkatli bir yolculuğa çıkmanın muhasebesini yaptığı hissini uyandırmaktadır.

\section{Plansız Gebelikte Dini ve Manevi Başa Çı1kma}

Her bireyin, hayata karşı benimsemiş olduğu kendisine özel bir oryantasyon sistemi vardır. $\mathrm{Bu}$ sistem, bireyin sahip olduğu dünya görüşüne göre kutsal veya seküler temelli olabilmektedir. Eğer din, kişinin oryantasyon sisteminin bir parçası ise olayları nasıl değerlendireceğini etkilemekte ve kişi bunu dini bir başa çıkma mekanizması olarak kullanmaktadır (Ayten, 2012). Pargament ve diğerleri (2011) dini başa çıkmayi; "yaşam stresörlerini kutsal ile açıklayarak ve anlamlandırarak başa çıkma çabası" olarak tanımlamaktadır. Yapılan çalışmalarda, dinin kişinin kontrol duygusunu geliştirdiği ve bunun ruh sağlığını olumlu yönde etkilediği hatta dini ve manevi başa çıkmanın, başa çıkma yöntemleri arasında en faydalı olanı olduğu tespit edilmiştir (Hood vd., 2009). Kişi, bir dini benimseyip onun değerleriyle yaşamaya karar verdiğinde, yaşamını anlamlı k1lan bir tercih yapmış demektir. Bu karar, kişinin anlamlı bir yaşam sürdürebilmesi için ihtiyaç duyduğu olumlu bakış açısını sağlayan, iyimserliğini artıran ve ümidini besleyen bir kuvvet olmaktadır (Frankl, 2017; Göcen, 2014).

Bir kriz döneminde, maneviyat, görünürde anlaş1lmaz olanı anlama ve görünürde yönetilemez olanı yönetme mücadelesinde kişiye yardımcı olmaktadır. Plansız gebelik yaşayan katılımcıların da bu durumdan yalnızca fiziksel, sosyal, psikolojik olarak değil, aynı zamanda manevi olarak da etkilendiği ve yaşadıkları süreci anlamlandırmak için dini başa çıkmayı kullandıkları görülmektedir. 
$\mathrm{Bu}$ çalışmanın araştırma sorusu olan "Katılımcıların yaşadığ 1 manevi süreçler plansız gebelik süreçlerini nasıl etkilemektedir ve plansız gebelikte yaşanan olumsuz duygu ve düşünceler ile başa çıkmada katılımcıların dini veya manevi başa çıkma durumları nasıldır?" sorusuna cevap almak amacıyla gebelik dönemlerindeki inançlarına yönelik pratikleri sorulduğunda "dua etmek" (K1, K2 K3, K5, K6, K7, K8, K9, K12, K13, K14, K15, K18, K19, K20, K21, K22, K23, K24, K25) "namaz k1lmak" (K4, K5, K8, K11, K16, K18, K23, K24) ve "Kur'an okumak" (K2, K6, K10, K14, K15, K18, K23) olmak üzere üç alt tema altında toplandığı görülmüştür:

Hayatın çeşitli alanlarındaki zorluklarla başa çıkmada kullanılan yöntemler listesinin başında dua gelmektedir (Horozcu, 2010; Arıc1, 2005). Allport'a (1965) göre birey duayı kendi iradesinin, niyetinin nihai sınırını içeren ve tanrıya ulaştıran bir araç olarak algılamaktadır ve genellikle bireyin niyeti, bir yardım beklentisi ve kendisine yöneldiği şeyden bir cevap umudu ile bütünleşmektedir. Dua ederek Allah'a ümit ve güvenle yönelen insan, kendi çaresizliğini itiraf etmekte fakat aynı zamanda hayata bir anlam yükleyerek yaşama arzusunu devam ettirmektedir. Dua eden insan Allah ile köklü bir bağ kurmakta ve O'nun yüce kudretine duyduğu derin itimadını dile getirmektedir (Göcen, 2015). Sıkıntılı zamanlarla başa çıkmak için kişinin yalnızlık hissini ortadan kaldırarak manevi bir destek unsuru mahiyetinde olan duanın yapılan birçok farklı çalışma neticesinde psiko-sosyal ve fiziksel sağlığı olumlu yönde etkilediği bilinmektedir (Albayrak, 2009; Gashi, 2016).

Katılımcıların hemen hepsi gebelik sürecinde dua ettiklerini, birçoğu da artık daha çok dua ettiğini veya dualarının formunun değişiklik gösterdiğini söylemişlerdir. Örneğin "Daha çok dua ediyorum artık, aslında bu beni bazen rahatsız da ediyor, sanki işim düşü̈̆̈̈ için Allaha yakınlaşmışım, çıkar iliş̧kimden dolayı daha fazla hatırlıyormuşum gibi suçlu hissettiriyor" diyen (K12) bir yandan içinde daha fazla dua etme hissinin bulunduğunu ama diğer yandan sıkıntılı anında daha fazla ihtiyaç duyduğu için yaratıcıya karşı kendisini mahcup hissettiğini ifade etmiştir. Gebelik sürecinde duanın etkisine karşı inançlarının daha da güçlendiğini söyleyen katılımcılar da olmuştur (K3, K9, K20). Kendisine dua edenlerin olduğunu belirten bir başka katılımcı da "Kayınvalidem, annem, teyzelerim hep güzel dualar edip destek oldular. Çok iyi hissettirdi bu bana. Ben de ilk 'neden oldu' diyordum ama şimdi sağllklı doğması için dua ediyorum hep" (K1) diyerek kendisine dua edenlerin onu müspet yönde etkilediğini ve dua etme pratiğini kendisinin de tecrübe etmeye başladığını belirtmiştir. Dua 
ederken kimsenin kendisine eşlik etmemesine sitem eden katılımc1lardan birisi ise; "Dualarım hep içimde kaldı ama eşlik eden kimse olmadl, olmasını çok isterdim ama" diyen (K22) de dua ederken eşlik eden kimsenin olmamasından dolay1 burukluk yaşadığını ve bunun kendisinde bir ukde olarak kaldığını söylemiştir.

Katılımcıların inançları doğrultusundaki tecrübe ettikleri değişiklikler konusunda ikinci sırayı namaz almıştır. Namaz ibadetinin ne gibi farklılıklarla tecrübe edildiğine baktığımızda, birbirinden farklı yansımaların olduğu görülmüştür. Manevi yönden kendilerini güçlendirmenin yolu olarak namaz kılmayı tercih edenler (K4, K16) olduğu gibi, daha önce namaz kılmadığı halde gebelik döneminde namaza başlayan (K11), devamlı olarak kılmaya başlamasa da belirli bir vaktin namazını zaman zaman kıldığını söyleyen de olmuştur: "Normalde beş vakit namaz kllan biri değilim ama gebeliğimde çok içimden gelerek kendiliğimden sabah namazlarına kalktığım oldu” (K5). Namaz k1lmakta güçlük çektiğini söyleyen K18 ise "Illk hamileliğimde hiç kaza namazı bırakmamaya gayret etmiştim. 2-3 defa hatim inmiştim. Ama bu gebeliğim plansız olunca maalesef daha az oldu, ibadetlerime özen gösteremedim şimdiye dek fakat bir an önce başlamak istiyorum" sözleriyle gebeliğinin plansız oluşundan ötürü istediği gibi bir süreç geçiremediğinden ve mutmain bir şekilde ibadet edemediğinden dem vurmuştur.

Katılımcıların gebelik sürecinde namaz konusunda üç gruba ayrıldığı söylenebilir. Birinci grubun daha önceden kıldığ şekliyle namaz kılmaya devam ettiği, ikinci grubun bu süreçte namaza başladığ 1 ve üçüncü grubun ise namaz kılmadığı fakat içten içe kılmayı istediği, namazlarında aksaklık yaşadıkları için vicdanen bu durumdan rahatsızlık duyduklarını ifade ettikleri görülmüştür. Namaz fiili bir duadır ve bireyin yaşadığı sıkıntı ve zorluklar karşısında mücadele edebilmesi için psikolojik bir güç kazandırır (Kardavi, 1986). Yaratıcı ile irtibatta kalmayı sağlayan namaz, aynı zamanda bireyin sorumluluk duygusunu da artırmaktadır. Yeni bir sorumluluk almaya, ebeveyn olmaya hazırlanan kat1lımcıların da bu süreçte namaza yönelmiş olmaları şaşırtıcı değildir.

Katılımcıların gebelik sürecindeki yaşam pratiklerinde 'dua' ve 'namaz'dan sonra 'Kur' an okumak' üzerine yoğunlaştıkları görülmüştür. Örneğin, “Günlük Kur'an-ı Kerim okuma sürem arttı" diyen (K15) daha önce periyodik olarak okuduğu Kur'an süresinden daha fazla okumaya başladığını söylemiştir. "illk haftalarda çok zor geldi ibadet özellikle namaz, bulantılardan ve diğer rahatsızlıklara dolayı ama toparlandıkça şimdi daha çok ibadet etmeye çalışlyorum, Kuran dinliyorum, okuyorum ve daha çok dua ediyorum" diyerek ilk dönemle- 
rinde fiziksel olarak gücünün çok yetmediğini fakat buna rağmen ibadet etmeyi ihmal etmediğini vurgulayan K23 ise Kur'anı yalnızca okumadığını, aynı zamanda Kur'an dinlemeye özen gösterdiğini de belirtmiştir (Kılıç, 2019).

Kur'an okumak; yaratıcıyla bağ kurmanın, irtibatta olmanın metafiziksel bir yoludur. Ruhsal iletişimi sözlü hale getiren bu bağ ise bireyin varlığını anlamlandırmasına yardım eder. Esas olan duygu ve histir, Kur'an okumak bireye yalnız olmadığını hissettirir. Kur'an'ın yaratıcının kendisine hitabı olduğunu bilen kişi, Arapça ifadesinin ne anlama geldiğini bilmese bile, o bağ hissetmektedir (Köse, 2020). Katılımcıların da bu bağı hissettikleri ve deneyimlemek istedikleri görülmektedir.

\section{Gebelerin Manevi Destek Algıları ve İhtiyaçları}

Teorik ve kavramsal pek çok çalışma, dini ve manevi faktörlerin etkilerinin ruh sağlığına olumlu etkilerinin olduğunu açıklamaktadır (Toussaint vd., 2012; Yapıc1, 2007). Plansız gebelik yaşayan katılımcıların da gebelik süreçlerinde dini ve manevi destek unsurlarından faydalandığı, bu çalışmanın bulguları arasındadir. Buna ek olarak, katılımciların profesyonel olarak manevi destek almaya ihtiyaç duyup duymadıkları ve böyle bir hizmeti almak isteyip istemedikleri anlaşılmak istenmiştir. Bu sebeple "Hem dini hem de psikolojik açıdan size manevi danışmanlık sunacak birisinden destek almayı ister miydiniz?" sorusu sorulmuş ve hepsinden böyle bir desteği almayı istediklerine dair cevaplar gelmiştir.

Bir manevi destek uzmanının danışmanlık sunmasını çok isteyen bir katılımc1, "Çok güzel olurdu. Mesela bağlatmanın günah olmadığını söylemiş bir hoca. Üçüncüden sonra onu okudum ve düşünmeye başladım bu doğumumdan sonra bağlatmayl" (K1) diyerek, ona destek sunacak kimsenin fikhi yönden bilgili ve dini ruhsatlardan kendisini haberdar edecek birisi olmasını istediğini belirtmiştir. Bir başka katılımc1 ise "Mesela şu an bu yöneltilen sorular psikolojik olarak destek oldu bana, insanı daha da rahatlattığı için konuşmak iyi geliyor. Daha önce dini olarak psikolojik destek annemi kaybettiğimde almıştım çok iyi gelmişti" (K7) sözleriyle, manevi destek hizmetinin kendisi için "dini olarak psikolojik destek" anlamına geldiğini ifade etmiş ve daha önce yas sürecinde böyle bir hizmet almanın kendisine iyi geldiğini söylemiştir.

Gebelik sürecinde, inançlarına yönelik bir destek bulup bulamadıkları sorulan katılımcıların çoğu (K1, K2, K4, K6, K7, K8, K10, K11, K14, K15, K16, K17, K19, K20, K22, K23, K24) müspet yönde cevap vermiş, bir k1smı ise inandı̆̆1 
dini değerler olmasaydı kürtaj1 düşüneceğini belirtmiştir (K1 K14, K16, K20, K22, K24). Nitekim, gönülden bağlılık duydukları inançlarının, hayatlarındaki önemli bir kararı vermelerinde büyük payının olduğunu vurgulayan katılımc1lardan birisi şu sözleri söylemiştir: "Bakamam, geleceğini nasıl sağlarım aldlrayım gibi düşüncelerden inancım sayesinde slyrıldım” (K1).

\section{Gebelerin Manevi Destek Uzmanlarından Beklentileri}

Katılımcılar, kendilerine dini ve psikolojik yönden danışmanlık hizmeti sunacak birisinden kişiden onlara "rehberlik etmeleri" (K3, K8, K10, K11, K15, K20, K21, K25) ve "motive etmeleri" (K1, K4, K5, K6, K13, K14, K16, K20, K22, K23, K25) beklediklerini ifade etmişlerdir. Katılımcıların bir kısmı, manevi destek uzmanlarının bu süreçte daha çok kendilerine yol gösterme noktasında destek olmalarını istediklerini söylemişlerdir. "Bilgili biriyle konuşmak rahatlatırdl, terapi gibi yani doğru yolu gösterirdi, kendimi iyi hissederdim" diyen (K11), hem dini hem de psikolojik açıdan danışmanlık hizmeti verebilecek birisinin yol göstericiliğinin, kendisine terapi gibi geleceğini söyleyerek onun için ruhsal bir sağaltım işlevi göreceğini ifade etmiştir. "Daha iyi anne olabilmenin, evlatlarımızı Allah rızası için yetiştirmenin nasıl olacă̆ına dair desteğini almak isterdim. Bazı zamanlar kendimi güçsüz ve yetersiz hissediyorum çünkü” diyen (K10) kendisini yetkin hissetmediği bir husus olan İslam'da anne olarak kadın konusunda bilgilendirilmeyi ve yönlendirilmeyi arzu ettiğini belirtmiştir. Anneliği konusunda kendisini eksik hisseden bir diğer katılımcı ise “Aslında önce neyi düzeltmem gerektiğini bilmediğim için bu konuda bana yardımcı olmasını çok isterdim. Anneliğimi çok problemli buluyorum, beni en fazla üzüp yıpratan şey bu çünkü” (K20) sözleriyle, anneliği özelinde bir yerlerde yanlış yaptığını hissettiğini fakat yanlışların nerelerde olduğu noktasında bir kılavuzun yol göstermesine gereksinim duyduğunu ifade etmiştir.

Manevi destek uzmanlarından beklenen rehberlik etmeleri hususu, yalnızca bilgilendirip yol göstermelerini değil, aynı zamanda gebeliği kabullenme ve sürece adapte olmalarını kolaylaştırma konusunu da kapsamaktadır. "ilk $z a^{-}$ manlarda mesela istemiyordum ve ne yapmam gerektiğini bilmiyordum sürekli eşime suç buluyordum, bunu kabullenmem konusunda yardım almayı çok isterdim" diyen (K21), ilk zamanlarının sancılı geçtiğini ve kendisini razı etmek için ehil birisinden destek almayı istediğini söylemiştir. "Ebeveyn olma, sorumluluk alma, duruma alı̧ma vb. konularında destek vermesini isterdim" diyen (K17) de (K21) ile benzer minvalde, gebeliği kabullenip, sorumluluğunu aldığ 
ebeveynliğe hazırlık sürecine geçmek için desteklenmeye ihtiyaç duyduğunu belirtmiştir. "Gebelik insanda bazen duygusal boşluklara ve sorgulamalara sürüklüyor. Bu yüzden sürekli okumasl, namazların aksatmaması ve muhabbeti ile kendisine getirecek birini istiyor. Gebelik hayret verici bir olay, buna tefekkür ile bakmama yardımcı olabilecek birisini isterdim" diyen (K15) ise kendisine bu yolda hatırlatmaları ve telkinleri ile eşlik edecek, gözden kaçırdıklarını fark ettirecek, yaratıcı ile olan bağını güçlendirmesine vesile olacak, bir yâren gibi destek verecek birisini istediğini söylemiştir.

Katılımcıların bir diğer kısmı ise manevi destek uzmanlarının bu süreçte daha çok kendilerini güdüleyerek destek olmalarını istediklerini söylemişlerdir. Örneğin "Illk başlarda çocuğun bir hediye olduğunu düşünmek aklına gelmiyor insanın, olumlu şeyler anlatarak destek olunsa güzel olurdu" diyen (K4), bebeğinin kendisine Allah'tan gelen bir hediye olduğunu hatırlatacak ve güzel sözlerle bunu pekiştirecek bir dış sesin destek olmasını istediğini belirtmiştir. Bir başka katılımc1 ise "Beni güncel dertlerimin arasından slyıracak, yaşadığım zorlukların bir karşıllı̆̆ olacağına dair sözleriyle şifa olacak etkin birisi veya da olanda hayır vardır diyecek, benim yalnız olmadığımı benim gibi birçok kimsenin olduğunu hatırlatacak birisi bana çok yardımcı olmuş olurdu" (K14) diyerek, yaşadıklarının bir ecri olduğunu ve mükafatını mutlaka alacağını telkin edecek, süreci anlamlandırmasına yardımcı olacak ve onun tek başına olmadığını, aynı durumu yaşayan başkalarının da olduğunu söyleyerek teselli edebilecek birisinden destek almaya ihtiyaç duyduğunu belirtmiştir. Yalnız olmadığının hatırlatılmasını isteyen bir başka katılıme da "Yani bir hoca kolay kolay aldır demez zaten, ben de aynı düşünüyorum. Ama sadece dini değil de duygu durumuтu da anlayan birisinin olmasını isterdim tabi ki. Bana yalnız olmadığımı hatırlatan destek veren birisi iyi olurdu" (K1) sözleriyle, manevi destek uzmanını zihninde ilk bir "hoca" olarak canlandırdığı fakat yalnızca inancına yönelik referanslarını kullanan değil, aynı zamanda plansız gebeliğinin iç dünyasında oluşturduğu ve uyandırdığı yankıları da anlayan ve elinden tutan birisi olmasını istediğini ifade etmiştir.

İnandıkları dinin değerleri ile bütünleşerek güçlenmek isteyen katılımcılar, bu konuda yüreklendirilmek istediklerini belirtmişlerdir: "Annelik sürecine hazırlanmak için inanç konusunda özellikle desteklenmeyi çok isterdim. Zaten elhamdülillah Müslüman insanlarız, onun için çocuk karnımda şu an ama onaylansaydım bu beni daha da rahatlatırdı" diyen (K22), çocuğunu doğurma kararını almasındaki tek faktörün, dini inancı olduğunu vurgulamış ve düşünce- 
lerinin bir uzman tarafından da kabul gördüğünü bilse çok daha iyi hissedeceği söylemiştir. "Insanın bu süreçte dengeleri değişebiliyor. Bazen inandı̆ğ şeyleri unutabiliyor. Tevekkülü, bunun aslında Allah'ın bir hikmeti olduğunu unutabiliyor. İbadetleri zaylfayabiliyor. Bu konuda gebe olan kişiye bunları tekrar hatırlaması için yardımcı olunabilitr" diyen (K23) ise Yaratıcı'ya teslim olmanın yaşattığı hafifliği gebenin sık sık tecrübe etmesini sağlamanın onu yardımc1 olacağını belirtmiş̧ir. Nitekim K23'ün de ifade ettiği gibi; tevekkül etmeyi zihinsel bir sığınak olarak metaforlaştırmak, insanı psikolojik açıdan rahatlatan ve mutlu olmasına zemin hazırlayan manevi bir yapı olarak ele alınmaktadır (Şahin, 2018).

Manevi destek uzmanlarından beklenen motive etmeleri hususunun; güdülemenin yanı sıra aynı zamanda şevklerini artırma ve enerjilerini yükseltme konusunu da kapsadığı görülmektedir. Örneğin bir katılımc1, "Efendimizin ve ailesinin yaşadiğı zorlukları anlatıp motive edebilir" (K6) sözleriyle, kendi yaşadığ sıkıntıları, Hz. Peygamber'in hayatından örnekler vererek anlamlandırmasında yardımc1 olabilecek bir uzman beklentisi olduğunu ifade etmiştir. "Ben bir vaizeye açıldım bu konuda; 'hocam çok kötüyüm' dedim, bir an enerjisinden etkilendim sanırım. O bana biraz nasihatte bulunmuştu; 'bunlar gebelikte çok normal şeyler, kendini suçlama, bunu yanlış bir şey gibi görme, mutlaka destek al, bunlar hepimizin yaşadiğı şeyler' vs. o an duymak istediğim şeylerdi" diyen (K20) ise daha önce bir din görevlisine başvurduğunu ve yaşadıklarını normalleştirmesine, kendisine yüklenmekten vazgeçmesine, suçluluk hissinden kurtulmasına yardımcı olacak sözlerle kendisini rahatlattı̆̆ını belirtmiştir. Nitekim psikolojik yardım alan dindar bireylerin manevi danışmanlık hizmetlerinden beklentilerinin incelendiği Çağlan ve Göcen'in (2020) çalışmasında da katılımcıların, birleştirici dil ve davranışlar bütünü ile yaklaşılarak manevi destek uygulamalarından faydalanmak istedikleri tespit edilmiştir.

\section{Tartışma, Sonuç ve Öneriler}

Bu çalışmanın temel amacı, plansız gebelik yaşayan anne adaylarının yaşadıkları müşterek tecrübeleri manevi ve psikolojik yönü ile ele alarak, gebeliği ve anneliği anlamlandırma ve yorumlama biçimlerini incelemek, plansız gebelikten anneliğe geçişte manevi yaşamlarının seyrini tespit etmeye çalışarak bu hayati döneme din psikolojisi çerçevesince yaklaşmaya çalışmaktır. Nitel araştırma yönteminin tercih edildiği bu çalışmada görüşme tekniği kullanılmış ve mevcut durumda plansız gebelik yaşayan evli Müslüman kadınlar tercih edilmiştir. 28,7 
yaş ortalamasında 25 kişiden oluşan çalışma grubuna, yarı yapılandırılmış görüşme formu kullanılarak, yaşadıkları plansız gebeliğe ilişkin sorular sorulmuş, bulgular betimsel ve içerik analiz yapılarak yorumlanmıştır.

Katılımcıların gebeliklerini öğrenme süreçlerinde yaşadıkları duygular, "şaşkınlık, şok”, “üzüntü”, “endişe kaygı, korku”, "ağlama hissi”, "sevinç ve mutsuzluk birlikte, duygu karmaşası" ve "engellenmişlik" olarak altı alt tema olarak tespit edilmiştir. Tahmin edildiği gibi, günlük rutinlerini beklenmedik bir şekilde bozan plansız gebelik haberini alan anne adayları ilk öğrendikleri anda olumlu duygular yaşamamıştır. İdeal gebelik tasavvurları ise dört alt tema olarak, "istekli ve planlı olmak", "fizyolojik ve psikolojik olarak hazır olmak", "çocuklarının arasında yeterli yaş farkının olması" ve "eş desteği almak" gibi koşullar çerçevesinde ifade edilmiştir. İnsan, yaşamını sürdürürken doğası gereği ön göremediklerini kontrol etmeye çalışmakta ve bunu yönettiğine dair bir inanca ihtiyaç duymaktadır. Gebeliğin de hem ruhu hem bedeni hem de ailevi ve sosyal yaşantıyı etkileyen önemli bir değişim kulvarı olduğu göz önüne alındığında, dengeyi korumak adına planlı bir şekilde gerçekleşmesini arzulamak makul görünmektedir.

Diğer yandan, katılımcıların anneliği anlamlandırma biçimleri incelendiğinde, ortaya "süper kahraman olmak" "sorumluluk sahibi olmak", "merhametli olmak", "sabırlı olmak", "fedakar olmak", "karşılıksız, koşulsuz, sonsuz sevgi", "mucize, lütuf, nimet" ve "arkadaş olmak" şeklinde sekiz alt tema çıkmıştır. Ortaya çıkan temalarda da görüldüğü üzere, annelik her zaman fedakarlık ve sorumluluk üzerine inşa edilen bir yaşam rolü olmuştur. Burada süper kahraman metaforundan da anlaşıldığı üzere, sevgi, merhamet, sabır, fedakarlık gibi zorlukları gündeme getirilse de bu güçlere sahip olmak mucize olarak görülmüştür. Katılımcıların beklenmedik bir gebelik yaşadıkları göz önüne alındığında, yine de anneliği yüküne rağmen yüceliği ile ele almaları olumlu bir anne tanımları olduğunu göstermektedir.

Plansız gebelikte anne adayını bebeğini dünyaya getirme noktasında arada bırakan etmenlerin anlaşılmaya çalışıldığı başlıkta ise alt temalar yedi farklı sebep olarak "ekonomik durum", "eşi ile ilişkisi", "sorumluluk almaya hazır hissetmemeleri”, "sağlık problemleri”, "hâlihazırda çocuk sahibi olmak", "ailevi sorunlar" ve "korku, kaygı" şeklinde ortaya çıkmıştır. Burada başı çeken faktörün ekonomik sebepler olması tarih boyunca insanları zorlayan nedenler sıralamasında çok değişiklik olmadığını göstermektedir. İslam dini içerisinde "rızık korkusuyla çocuklarınıza kıymayın” (İsra, 17/31) şeklindeki uyarı da bu- 
nun kanıtıdır. Bir bebeğin maddi külfetine karşılık yine İslam geleneğinde o bebeğin kendi rızkıyla beraber geleceğine dair olan inanç da bu düşüncenin bir sonucudur. Gelişen şartlarla birlikte daha fazla imkânın olduğu dünyada her doğan çocuğun aynı düzeyde imkânla karşılaşmamasının onu dünyaya getiren anneye kaygı vermesi de makuldür. Ayrıca, önceki dönemlere kıyasla çok daha fazla gündemde olan ve etkileri üzerine araştırmalar yapılan "eş desteği” de bugün ihtiyaç duyulan baba ebeveynliğini daha da öne çıkaran bir etmen haline getirmiştir (Duman, 2019; Ilska ve Basista, 2017).

Son olarak plansız gebelikte manevi yaşam ele alınmış ve gebelikte oryantasyon sürecinin bir parçası olan dini ve manevi süreçleri daha derinden incelemek maksadıyla plansız gebelikte ibadetlerin seyrine dair temalar belirlenmeye çalışılmış ve bunun neticesinde katılımcıların dini ve manevi tecrübelerinin "dua etmek", "namaz kılmak" ve "Kur'an okumak" gibi dini ve manevi başa çıkma mekanizmalarını kullandıkları üç alt tema şeklinde belirlenmiştir.

İnançlar ve onlardan doğan eylemler insanın kendi kutsalı ile olan ilişkisi üzerinde temellenmektedir (Göcen, 2018). İnsanın her şeyi kontrol edemediğini anlayıp kendi sınırlarını derinden duyumsayıp güçsüz hissettiği zor zamanlarında, her şeyi yöneten ve her yönden güçlü olan kutsalına yönelmesi bekelenen bir durumdur. Kişi kendi kontolsüzlüğünü akışa bırakırken, düzensizliğe de bir düzen verene sığınma ihtiyacı gösterebilmektedir. Burada da beklenmedik bir bebek haberiyle karşılaşan kadınların kendi içlerindeki dar dairenin dışına ç1karak üst anlamı görmeye çalıştığı, kendilerinden daha güçlü ve tüm şartlara hakimyet kurana teslim olma ihtiyaçları içinde namaz kılmak, kur'an okumak ve her ikisini de içine alan geniş tabanlı olarak dua yani Allah'la iletişim olarak karşımıza çıkmaktadır.

Katılımcıların manevi destek algı ve ihtiyaçlarına dair görüşleri değerlendirildiğinde tamamının dini ve psikolojik açıdan danışmanlık hizmeti verecek bir uzmandan destek almak istediği görülmüştür (Çağlan, 2020; Gügen, 2019). Katılımciların manevi destek uzmanlarından beklentilerinin neler olduğu incelendiğinde ise gebeliği kabullenme ve sürece adapte olmaları konusunda yol gösterici olup destek olmalarına dair iki üst tema olarak "rehberlik etmesi beklentisi" ve bu süreçte yaşadıklarının ecrini hatırlatarak güdüleyen, yalnız olmadıklarını hissettiren, teselli eden, süreci anlamlandırmalarına yardımcı olmalarını kapsayan "motive etmesi beklentisi" taşıdıkları belirlenmiştir. Gebelerin manevi destek konusundaki profesyonel destek arayışlarının günümüzde "doğum destekçisi” şeklinde bir açılım gösterdiği görülmektedir (Bekmezci vd. 2016).

Katılımcıların inançlarından aldıkları motivasyonları belirlemek amacıyla 
inançlarına yönelik bir destek bulup bulamadıklarına dair soruya verdikleri cevaplar ele alındığında hepsi inançlarından büyük bir destek aldıklarını söylemişler, bir kısmı ise yalnızca inandığı dini değerlerin kürtajı düşünmesine engel olduğunu ifade ederek gönülden bağlılık duydukları inançlarının bu önemli kararı almalarındaki rolünün büyüklüğünü vurgulamışlardır.

Gebelik süreçlerinde yakın çevrelerinden manevi destek gören veya psikolojik dayanıklılığı güçlü olan ve içsel motivasyonları ile kendilerini manevi yönden besleyebilen katılımcıların, çevrelerinden manevi destek görmeyen veya kendi motivasyon kaynaklarını keşfetme imkanı bulamayan katılımcılara kıyasla gebelik süreçlerinde daha az korku, üzüntü, stres ve gerginlik yaşad1ğ1, duygusal yoğunluklarının nispeten daha stabil olduğu ve plansız gebeliğin olumsuz yönlerini daha az gündeme getirdikleri görülmüştür (Berthelon vd., 2018; Bahk vd., 2015). Yapılan bir çok çalışma, plansız ve stresli geçen gebeliklerden doğan çocukların fiziksel ve bilişsel gelişim düzeylerinin daha zayıf olduğunu ve ilerleyen yaşamlarının daha olumsuz seyrettiğini söylemektedir (Coussons-Read, 2013; Bradley, 2013; De La Rochebrochard ve Joshi, 2013; David, 2006). Plansız gebeliklerin bu uzun soluklu etkisi düşünüldüğünde, anne adaylarının manevi yönden desteklenmesi yalnızca daha sağlıklı bir gebelik dönemi geçirmelerinin sağlamayacak, aynı zamanda dünyaya gelecek çocukların yaşamlarında koruyucu önleyici bir işlev görecektir.

Araştırmanın teorik çerçevesinde değinilen "baba desteğinin rolü” konusu, bulguları değerlendirirken hem plansız gebelik yaşayan kadınların ideal gebelik algılarında "eş desteği almak" faktörü olarak, hem de gebelik süreçlerinde desteğine en çok ihtiyaç duydukları kimselerde ilk sırada "eşlerinin" yer almasıyla karşımıza çıkmış ve babaların plansız gebeliklerdeki rolüne dair bütünsel bir perspektif sunmuştur. Bu çalışma her ne kadar plansız gebelik yaşayan kadınları öncelemiş olsa da, anne adayından sonra bu süreci en çok etkileyen ve bu süreçten en çok etkilenen kişi olarak baba adayları da gündeme gelmiştir. Bu sebeple, ihmal edilen bir konunun paydaşı olan babanın da müstakil çalışmalarda yerini alması elzem görünmektedir.

Araştırmanın hem sınırlılıkları hem de nitel bir araştırma deseninde hazırlanmasından dolayı söylemek gerekir ki, bu çalışmanın bulguları herhangi bir genelleme niteliği taşımamaktadır ve görüşme yapılan 25 katılımcının kendi gebelik hikayesi ile sınırlıdır. Her ne kadar böyle bir şart aranmasa da katılımcıların hepsi evli ve dini inancı İslam olan bireylerle sınırlı olmuştur. Katılımcıla- 
rın eğitim ve sosyoekonomik durumlarının bilgisi alınmış olsa da bu konudaki farklılıkların plansız gebelikte etkilerinin olup olmadığı açık ve net bir şekilde ortaya konulamamıştır. Burada plansız bir gebelik olmasına rağmen bebeğini dünyaya getirme kararını vermiş kadınların görüşleri incelenmiştir. Öte taraftan bu tercihin aksi yönünde karar almış kadınlar üzerine özellikle dini ve manevi başa çıkma süreçleri, dindar kadınların kendi dini yaşamlarıyla kürtaj kararını aldıktan sonraki yaşam durumları gibi konular incelenmeyi beklemektedir. Genelde toplum sağlığı özelde de kadın, çocuk ve aile sağlığının korunması ve de iyileştirilmesi için özellikle yaşanmamış gibi davranmanın getirdiği birçok psikolojik ve sosyal etmen akademik sahaya henüz yansımasa da günlük hayatta karşımıza dramatik olarak çıkmaktadır.

$\mathrm{Bu}$ çalışmanın bulguları ve araştırma esnasında yapılan gözlemler doğrultusunda plansız gebelik yaşayan kadınların bu süreçlerini daha sağlıklı yürütmelerinde yardımcı olmak için verilebilecek öneriler şu şekilde ifade edilebilir: (i) Az sayıda çalışmanın olduğu plansız gebeliklere dair, psikoloji ve din psikolojisinin ortak nicel ve nitel saha araştırmaları yapması yapılabilir. (ii) Plansız gebeliklerde sürecin paydaşı ve ebeveynlerden birisi olan eş de bu durumdan etkilenmektedir. Doğrudan baba ve eş rolünü de baz alan, baba adaylarının dini/ manevi yaşamlarının, inançlarına dair motivasyonlarının ve başa çıkmalarının plansız çocuk sahibi olmaları durumuna etkisini konu alan müstakil çalışmalar yapılabilir. (iii) Gebelik dönemi ve doğum sonrasına yönelik kadınların yaşadığı psikolojik ve fizyolojik değişikliklere dair çeşitli müdahale ve destek programları olmasına karşın, plansız gebelik özelinde kadının yeni rolüne ve sorumluklarına uyum sağlamasını kolaylaştıracak hiç bir müdahale programı planlanmamıştır. Plansız gebelik yaşayan anne adayının değişen dünyasına adapte olmasında yardımcı olacak, manevi ve sosyal destek alabileceği platformlar oluşturulmalıdır.

\section{Kaynakça}

Abajobir, A. A., Alati, R., Kisely, S., Najman, J. M. (2017). Antecedents and maternal health outcomes of unintended pregnancy: a systematic review. Ethiop Med J. 55(4), 325-336.

Albayrak, A. (2009). Üniversite Gençlerinin Dua Tutum ve Davranışları. Karadeniz Basın Yayım, Rize.

Ali, A. (2016). Relationship between Unwanted Pregnancy and Health-Related Quality of Life in Pregnant Women. Journal of the College of Physicians 
and Surgeons Pakistan. 26(6). 507-512.

Allport, G.W. (1965). The Individual and His Religion. Macmillan Company. New York. Arıcı, A. (2005). Ergenlerde Din̂̂ Başaçıkma Yöntemi Olarak Dua.Yüksek Lisans Tezi, Uludağ Üniversitesi Sosyal Bilimler Enstitüsü.

Arslan, İ. ve Mete, S. (2004). Beklenmeyen Gebelikler, Atatürk Üniversitesi Hemşirelik Yüksekokulu Dergisi. S.8(1).

Ayten, A. (2012). Tanrı'ya Sı̆̆ınmak: Dini Başa Çıkma Üzerine Psiko-Sosyal Bir Araştırma. İstanbul. İz Yayıncılık.

Ayten, A.(2018). Din ve Sağlık Kavram, Kuram ve Araştırma. İstanbul.Marmara Akademi Yayınları.

Bahk, J., Yun, S.-C., Kim, Y., \& Khang, Y.-H. (2015). Impact of unintended pregnancy on maternal mental health: A causal analysis using follow up data of the Panel Study on Korean Children (PSKC). BMC Pregnancy and Childbirth, 15(1), 85. https://doi.org/10.1186/s12884-015-0505-4

Barrett, G., \& Wellings, K. (2002). What is a 'planned' pregnancy? Empirical data from a British study. Social Science \& Medicine, 55(4), 545-557. https://doi. org/10.1016/S0277-9536(01)00187-3

Berthelon, M. Kruger, D. Sanchez, R. (2018). "Maternal Stress During Pregnancy and Early Childhood Development". IZA Institute of Labor Economics. S.11452.

Bekmezci, H., Özkan, H., Bayrak, S., Öztürk, T., \& Toprak, N. (2016). Gebelerin Doğum Koçluğu Hakkındaki Bilgi, Görüş Ve Tutumlarının Değerlendirilmesi. Journal of Anatolia Nursing and Health Sciences, 19(1). https://doi. org/10.17049/ahsbd.05630

Bradley Sarah E. K. (2013). The consequences of unintended pregnancy on child health. Population Association of America annual conference.

Coussons-Read, M. E. (2013). Effects of prenatal stress on pregnancy and human development: Mechanisms and pathways. Obstetric Medicine, 6(2), 52-57. https://doi.org/10.1177/1753495x12473751

Çağlan, K. \& Göcen, G. (2020). Psikolojik Yardım Almanın Dini / Manevi Açıdan Damgalanması ve Bu Süreci Yaşayanların Manevi Danışmanlık Hizmetlerinden Beklentileri. Değgerler Ĕ̈itimi Dergisi. https://doi.org/10.34234/ded.617263

David, H. P. (2006). Born Unwanted, 35 Years Later: The Prague Study. Reproductive Health Matters, 14(27), 181-190. https://doi.org/10.1016/S09688080(06)27219-7

De La Rochebrochard, E., \& Joshi, H. (2013). Children Born After Unplanned Pregnancies and Cognitive Development at 3 Years: Social Differentials in 
the United Kingdom Millennium Cohort. American Journal of Epidemiology, 178(6), 910-920. https://doi.org/10.1093/aje/kwt063

Deklava, L., Lubina, K., Circenis, K., Sudraba, V., \& Millere, I. (2015). Causes of Anxiety during Pregnancy. Procedia - Social and Behavioral Sciences, 205, 623-626. https://doi.org/10.1016/j.sbspro.2015.09.097

Duman, B.U. (2019). Postpartum Depresyon, Eş Desteği ve Duygu Düzenleme Güçlükleri Arasındaki İlişki. Yüksek Lisans Tezi. Maltepe Üniversitesi Sosyal Bilimler Enstitüsü.

Dunkel Schetter, C., \& Tanner, L. (2012). Anxiety, depression and stress in pregnancy: Implications for mothers, children, research, and practice. Current Opinion in Psychiatry, 25(2), 141-148. https://doi.org/10.1097/ YCO.0b013e3283503680

Ersoy, E., Karasu, Y., Çelik, E. Y., Ersoy, A. Ö., Tokmak, A., \& Taşçı, Y. (2015). Individual features and contraceptive attitudes of women who had unintended pregnancy. Journal of Clinical and Experimental Investigations, 6(3). https://doi.org/10.5799/ahinjs.01.2015.03.0528

Figueiredo, B., Field, T., Diego, M., Hernandez-Reif, M., Deeds, O., \& Ascencio, A. (2008). Partner relationships during the transition to parenthood. Journal of Reproductive and Infant Psychology, 26(2), 99-107. https://doi. org/10.1080/02646830701873057

Frankl, V. (2017). İnsanın Anlam Arayışı. Çev. Selçuk Budak, 37. Bsk., İstanbul, Okuyanus Yay.

Fromm, E. (1985). Sevme Sanatı, Say Yayınları, İstanbul.

Gashi, F. (2016). Dua ve Hayat Memnuniyeti Üzerine Karşılaştırmalı Bir Araştırma. Uludağ Üniversitesi İlahiyat Fakültesi Dergisi 25: 2, 1-29.

Göcen, G. (2018) .Psikoloji Mitoloji ve Din. İstanbul. Kaknüs Yayınları.

Göcen, G. (2015). Tüp Bebek Tedavisi Almış Kadınların Dinî Başa Çıkma Süreçleri ve Dinî Yaşantıları Üzerine Nitel Bir Araştırma. İstanbul Üniversitesi İlahiyat Fakültesi Dergisi. 32. 165-217.

Göcen, G. (2014). Şükür, Pozitif Psikolojiden Din Psikolojisine Köprü. İstanbul: Dem Yayınları

Gügen, B. (2019). Gebelik Sürecindeki Kadınlarda Manevi İyi Oluş İle Hayat Memnuniyeti İlişkisi. Yüksek Lisans Tezi. İstanbul Üniversitesi Sosyal Bilimler Enstitüsü.

Hacettepe Üniversitesi Nüfus Etütleri Enstitüsü. (2019). 2018 Türkiye Nüfus ve Sağlık Araştırması. T.C. Cumhurbaşkanlığ 1 Strateji ve Bütçe Başkanlığı ve 
TÜBITAK, Ankara Türkiye.

Hedayat, K. M., Shooshtarizadeh, P., \& Raza, M. (2006). Therapeutic abortion in Islam: Contemporary views of Muslim Shiite scholars and effect of recent Iranian legislation. Journal of Medical Ethics, 32(11), 652-657. https://doi. org/10.1136/jme.2005.015289

Hill, P. C.; Pargament, K. I. (2015). Din ve Maneviyatın Kavramlaştırılması ve Ölçülmesindeki Gelişmeler, Beden ve Ruh Sağlığı Araştırmaları İçin Olası Bulgular. Çev. Mustafa Ulu, Bilimname, 2015, .1 (28). s.343- 368.

Hood, R. W., Hill, P. C., \& Spilka, B. (2009). The psychology of religion: An empirical approach (4th ed). Guilford Press.

Horozcu, Ü. (2010). Din Psikolojisi Açısından Dünyevi İstek Duaları, Doktora Tezi, İstanbul Üniversitesi Sosyal Bilimler Enstitüsü.

Ilska, M., \& Przybyła-Basista, H. (2017). Partner support as a mediator of the relationship between prenatal concerns and psychological well-being in pregnant women. Health Psychology Report, 4, 285-295. https://doi.org/10.5114/ hpr.2017.68235

Joaquim, R. M. (2018). Psychobiology of Sadness: Functional Aspects in Human Evolution. EC Psychology and Psychiatry. 7(12), 1015-1022.

Jung, C. G. (2005). Modern Man in Search of a Soul. Routledge Classics.

Karaçam, Z., Şen, E., \& Amanak, K. (2010). Effects of unplanned pregnancy on neonatal health in Turkey: A case-control study: Effects of unplanned pregnancy on babies. International Journal of Nursing Practice, 16(6), 555-563. https://doi.org/10.1111/j.1440-172X.2010.01881.x

Kardavi, Y. (1986). Ibadet. çev. Hüsamettin Cemal. Pınar Matbaacılık. Trabzon.

Karamustafa, F.C. (2017). Postpartum Depresyonda Evlilik Doyumu Ve Benlik Saygısının İncelenmesi. Yüksek Lisans Tezi. Işık Üniversitesi Sosyal Bilimler Enstitüsü.

Khajehei, M. (2015). Mental health of perinatal women. World Journal of Obstetrics and Gynecology, 4(2), 46. https://doi.org/10.5317/wjog.v4.i2.46

Kılıç, D. (2019). Gebelik Sürecinde Dini Manevi Yaşam Üzerine Nitel Bir Araştırma. Yüksek Lisans Tezi. İstanbul Üniversitesi Sosyal Bilimler Enstitüsü.

Köse, A. (2020). “Kuran Okumak İnsanı Neden Rahatlatır?”. (Çevrimiçi).

http://www.aktuelpsikoloji.com/kuran-okumak-insani-neden-rahatlatir-7272h.htm. Erişim Tarihi: 10.04.2020.

Kroelinger, C. D., \& Oths, K. S. (2000). Partner Support and Pregnancy Wantedness. Birth, 27(2), 112-119. https://doi.org/10.1046/j.1523-536x.2000.00112.x 
Liamputtong, P. (200). Motherhood, Risk And Responsibility: Infant Care In Northern Thailand. Journal of Family Studies.

Manap, J. Fazilah, I. Syaidatun, N.A.Z. Zuraidah, A. (2015). How Do Mothers Nurture Love Via Parenting?. Jurnal Psikologi Malaysia. 29(2).

Mellers, B., Fincher, K., Drummond, C., \& Bigony, M. (2013). Surprise. Progress in Brain Research (C. 202, ss. 3-19). Elsevier. https://doi.org/10.1016/B9780-444-62604-2.00001-0

Murphy, E. (2000). Risk, responsibility, and rhetoricin infant feeding. Journal of Contemporary Ethnography. 29(3): 291-325.

Mutmainnah, M., \& Afiyanti, Y. (2019). The experiences of spirituality during pregnancy and child birth in Indonesian muslim women. Enfermería Clínica, 29, 495-499. https://doi.org/10.1016/j.enfcli.2019.04.074

Neuman W. L. (2017). Toplumsal Araştırma Yöntemleri: Nitel ve Nicel Yaklaşımlar. çev. Sedef Özge. c.1. Yayın Odası. Ankara.

Uysal, S. (2021). Gelenek ve Gelecek Arasında İslami Psikoloji. Çamlıca Yayınları. İstanbul.

Pakzad, M., Dolatian, M., Jahangiri, Y., Nasiri, M., \& Alidoust Dargah, F. (2018). The Correlation between Islamic Lifestyle and Pregnancy-Specific Stress: A Cross-Sectional, Correlational Study. Open Access Macedonian Journal of Medical Sciences, 6(6), 1163-1167. https://doi.org/10.3889/oamjms.2018.104

Pargament, K., Feuille, M., \& Burdzy, D. (2011). The Brief RCOPE: Current Psychometric Status of a Short Measure of Religious Coping. Religions, 2(1), 51-76. https://doi.org/10.3390/rel2010051

Røsand, G.-M. B., Slinning, K., Eberhard-Gran, M., Røysamb, E., \& Tambs, K. (2011). Partner relationship satisfaction and maternal emotional distress in early pregnancy. BMC Public Health, 11(1), 161. https://doi. org/10.1186/1471-2458-11-161

Şahin, M. (2018). Dini Bir Değer Olarak Tevekkül Yöneliminin Psikolojik Sebep ve Sonuçları Üzerine Araştırma. Yayımlanmamış Doktora Tezi. Uludağ Üniversitesi, Sosyal Bilimler Enstitüsü, Bursa.

Taner, S. (2014). Planlanmamış Gebeliklerin Doğum Sonrası Erken Dönemdeki Annelik Davranışına Etkisi. Yüksek Lisans Tezi. Adnan Menderes Üniversitesi Sağlık Bilimleri Enstitüsü.

Toussaint, L., Webb, J. R., \& Keltner, W. (2012). Religion, spirituality, and mental health. In J. D. Aten, K. A. O'Grady, \& E. L. Worthington, Jr. (Eds.), The psychology of religion and spirituality for clinicians: Using research in your 
practice (331-356). Routledge/Taylor \& Francis Group.

Tuğrul, Y. G. (2018). Dindar Kadınların Annelik Algısı: Reçel Blog ve Müslüman Anneler Blogunun Karşılaştırmalı Analizi. Fe Dergi. 10(2).

Türkiye İstatistik Kurumu. Doğum İstatistikleri. (Çevrimiçi). www.tuik.gov.tr. Erişim: 15.05.2021.

Yali, A. M., \& Lobel, M. (1999). Coping and distress in pregnancy: An investigation of medically high risk women. Journal of Psychosomatic Obstetrics \& Gynecology, 20(1), 39-52. https://doi.org/10.3109/01674829909075575

Yapıc1, A. (2007). Ruh sağllğı ve din: Psiko-sosyal uyum ve dindarlı. Karahan Yayınları.

Yıldırım, A. Ve Şimşek, H. (2013). Sosyal Bilimlerde Nitel Araştırma Yöntemleri. Ankara: Seçkin Yayınları.

Yıldız, E. (2019). İlkokul 4. Sinı Öğrencilerinin Annelik Değerine Yükledikleri Anlamların Metaforlar Aracıllğıyla İncelenmesi. Yüksek Lisans Tezi. Erzincan Binali Yıldırım Üniversitesi Sosyal Bilimler Enstitüsü. 
Extended Abstract

\title{
Investigation of Religious, Spiritual and Psychological Conditions of Women During Unintended Pregnancy
}

\author{
Amine Hümeyra BULDUR, Corresponding Author, Ph.D. Student. \\ İstanbul University Social Science Institute, İstanbul / Turkey \\ aminehumeyra@gmail.com \\ https://orcid.org/0000-0001-6187-077X
}

Gülüşan GÖCEN, Associate Professor

İstanbul University Theology of Faculty, İstanbul / Turkey

gulusan.gocen@istanbul.edu.tr

https://orcid.org/0000-0003-4856-9653

Article Type: Research Article

https://doi.org/10.34234/ded.899968

Received Date: 13.10 .2021

Accepted Date: 26.11 .2021

Published Date: 25.12 .2021

\section{Introduction}

Deciding to be a parent is not always planned, voluntary and conscious. Pregnant women's reactions to delivery may differ if the pregnancy is planned or unintended. Planned pregnancy is described as a desired and safely sustained pregnancy. Unintended pregnancy is described as a safe pregnancy when it is desired in the ongoing process, or as a pregnancy that leads to abortion when not wanted (Abajobir et al., 2017; Ersoy et al., 2015; Karaçam et al., 2010; Arslan and Mete, 2005).

Unintended pregnancy is a widespread problem worldwide with potentially significant personal, familial and social consequences. Globally, 40\% of preg- 
nancies are unintended (Abajobir et al., 2017). Unintended pregnancy, which is common in both developed and developing countries; is seen as one of the main problems that need to be prevtend or reduced, especially in developing countries, as it causes various negative consequences for the mother and baby in the long term (Ersoy, 2015). The negative consequences of these pregnancies directly affect the mother, baby and family (Khajehei, 2015; Taner, 2014) and have an indirect impact on the society (Bahk et al. 2015; Arslan and Mete, 2004). For this reason, it is important to conduct research on the nature of unintended pregnancy and its effects on pregnant women so that the negative consequences of unintended pregnancy could be prevented.

The integrity of human biopsychosocial and spiritual well-being is also valid for pregnant women, and being human requires being in a state of complete well-being. Therefore, in order to talk about a full recovery, spiritual functioning as well as physical, emotional and cognitive functioning should be taken into account (Hill \& Pargament, 2015).

In this respect, the research questions of this article are as follows:

- Considering the psychology and physiology of pregnancy, how does unintended pregnancy affect the transition to motherhood and making sense of motherhood?

- What are the reasons that causes dilemma for women with unintended pregnancy that affect their decision regarding giving birth to a baby and what motivate them?

- How do the spiritual values of the participants affect the unintended pregnancy processes?

- What is the religious or spiritual coping mechanism of the participants that helps them in dealing with the negative feelings and thoughts experienced in unintended pregnancy?

\section{Method}

\section{Research Design}

This research is designed as a qualitative case study with phenomenological approach. Phenomenology is an in-depth and comprehensive study and explanation of a phenomenon that we have previously learned in a real context 
(Yıldırım and Şimşek, 2016). From purposeful sampling methods, snowball sampling, criterion sampling are used in this study. Accordingly, the study group consists of married and Muslim women who are currently experiencing an unintended pregnancy.

\section{Data Collection and Analysis}

The data were collected between in August-November 2018. The data collection tools are interview and observation. Semi-structured interview technique was used in the research. Interview technique in qualitative research enables rich descriptions and is more interested in the diversity, depth, texture and emotion of the data (Neuman, 2017). After getting the permission from participants, the interviews were recorded, then transcribed and analyzed. The participants were referred to by numbers instead of names, by assigning numbers to reach participant. In this way, their identities were kept anonymous. Descriptive and content analysis method were used to analyze the data. In addition to the detailed descriptions, direct quotations were frequently included. The findings were interpreted with support of the researcher's observations.

\section{Conclusion, Discussion and Suggestions}

The main purpose of this study is to examine the ways of interpreting pregnancy and motherhood by considering the common experiences of expectant mothers who have had an unintended pregnancy in terms of its spiritual and psychological aspects, and to approach this vital period within the framework of the psychology of religion by trying to comprehend the state of their spiritual life in the transition from unintended pregnancy to motherhood. In this study, in which the qualitative research method was preferred, the interview technique was used and married Muslim women who are currently pregnant were preferred. The study group consisting of 25 people with an average age of 28.7, who were asked questions about the unintended pregnancy they experienced using a semi-structured interview form, and the findings were interpreted by descriptive and content analysis.

As anticipated, expectant mothers who receive the news of an unintended pregnancy that unexpectedly disrupt the dynamic of their daily routine do not experience positive emotions when they first learn about it. The emotions experienced by the participants during the learning process of their pregnancy; were 
divided under six sub-themes; "confusion, shock", "sadness", "anxiety, worry, fear", "feeling of crying", "joy and unhappiness together, emotional confusion" and "sense of frustration". Whereas ideal pregnancy conceptions put into four sub-themes; "being willing and planned", "being physiologically and psychologically ready", "having a sufficient age difference between their children" and "receiving spousal support". While living his life, human beings by natüre try to control what they cannot foresee and needs a belief that they can manage it. Considering that pregnancy is an important change that affects both the soul, the body, and the family and social life, it seems reasonable to wish it to take place in a planned way in order to maintain the balance.

On the other hand, when the participants' ways of interpreting motherhood are examined; eight sub-themes emerged such as: "being a superhero", "being responsible", "being compassionate", "being patient", "sacrifice", "unconditional, unconditional love", "miracle, grace, blessing" and "being friends". As can be seen in the emerging themes, motherhood has always been a life role built on sacrifice and responsibility. As can be understood from the superhero metaphor here, although challenges stem from love, compassion, patience and sacrifice are brought to the agenda, having these challenges is seen as a miracle. The fact that even participants who experienced an unexpected pregnancy still consider motherhood with dignity despite the burden it places on them, shows that they have a positive mother definition.

When it comes to understand the factors that affect the mother-to-be' decisions regarding giving birth or not in unintended pregnancy, seven sub-themes are emerged; "economic situation", "relationship with their spouse", "not feeling ready to take responsibility", "health problems", "currently having children", "family problems" and "fear and anxiety". In the world where there are more opportunities with the improving conditions, it is likely that the mother who gave birth to worry that her child might not get the same level of opportunity.

In addition, "spousal support", which is more popular issue than in previous periods and whose effects have been scrutinized, has made parenting a factor that is more relevant today than before (Duman, 2019; Ilska \& Basista, 2017).

Finally, the spiritual life in unintended pregnancy was discussed and the themes related to the act of worship in unintended pregnancy were tried to be determined in order to examine the religious and spiritual processes that accompanying the orientation process in pregnancy. As a result, the religious and spiritual experiences of the participants were divided as three sub-themes in 
which they used religious and spiritual coping mechanisms such as "making duah", "performing salah" and "reading the Qur'an".

When the opinions of the participants about their perceptions and needs of spiritual support were evaluated, it was seen that all of them wanted to receive support from an expert who would provide religious and psychological counseling (Çağlan, 2020; Gügen, 2019). When the expectations of the participants from the spiritual support specialists are examined; two themes have been determined as "Expectation for Guidance" and "Expectation to Motivate". The pregnant women search for professional support has led to the develpment of a new concept which is called "birth supporter" (Bekmezci et al. 2016).

When the answers of the participants to the question about whether they could find any comfort through their religious beliefs, all of them said that they received great support from their religious beliefs. Some participations even stated that only their religious values prevented them from thinking about abortion, and they emphasized the importance of their faith in making this important decision.

In line with the findings of this study and the observations made during the research, suggestions that can help women with unintended pregnancies to carry out these processes more healthily can be expressed as follows: more quantitative and qualitative field studies can be done about unintended pregnancies as there are few studies related to psychology and psychology of religion diciplines (i). In unintended pregnancies, the partner of the mother also got affected by the situation. Independent studies can be conducted on the impact of the father candidates' religious/spiritual lives, their motivations regarding their beliefs and their coping mechanism, which are directly related to the role of father or spouse, and having unintended child. (ii) Although there are various intervention and support programs regarding the psychological and physiological changes experienced by women during pregnancy and postpartum, no intervention program has been planned to facilitate the adaptation of women to their new role and responsibilities in the context of unintended pregnancy. Platforms should be created to help the expectant mothers who have an unintended pregnancy adapt to their changing world and receive moral and social support (iii). 
Etik Beyan / Ethical Statement: Bu çalışmanın hazırlanma sürecinde bilimsel ve etik ilkelere uyulduğu ve yararlanılan tüm çalışmaların kaynakçada belirtildiği beyan olunur. / It is declared that scientific and ethical principles have been followed while carrying out and writing this study and that all the sources used have been properly cited.

Finansman / Funding: Yazarlar, bu araştırmayı desteklemek için herhangi bir dış fon almadıklarını kabul ederler. / The authors acknowledge that they recevied no external funding in support of this research.

Yazar (lar) / Author (s): Amine Hümeyra BULDUR, Gülüşan GÖCEN

Yazar Katkıları / Author Contributions: Amine Hümeyra BULDUR (\%50), Gülüşan GÖCEN (\%50)

Çıkar Çatışması / Competing Interests: Yazarlar, çıkar çatışması olmadığını beyan ederler. / The authors declare that they have no competing interests. 